\title{
Volcanic soils and landslides: a case study of the island of Ischia (southern Italy) and its relationship with other Campania events
}

\author{
S. Vingiani ${ }^{1}$, G. Mele ${ }^{2}$, R. De Mascellis ${ }^{2}$, F. Terribile ${ }^{1}$, and A. Basile ${ }^{2}$ \\ ${ }^{1}$ Department of Agricultural Sciences, University of Naples Federico II, Portici NA, Italy \\ ${ }^{2}$ National Research Council, Institute of Agriculture and Forestry in the Mediterranean (CNR ISAFOM), Ercolano NA, Italy \\ Correspondence to: S. Vingiani (simona.vingiani@unina.it)
}

Received: 27 November 2014 - Published in Solid Earth Discuss.: 06 January 2015

Revised: 12 May 2015 - Accepted: 14 May 2015 - Published: 26 June 2015

\begin{abstract}
An integrated investigation was carried out on the volcanic soils involved in the landslide phenomena that occurred in 2006 at Mt. Vezzi on the island of Ischia (southern Italy). Chemical (soil pH, organic carbon content, exchangeable cations and cation exchange capacity, electrical conductivity, $\mathrm{Na}$ adsorption ratio and $\mathrm{Al}, \mathrm{Fe}$ and $\mathrm{Si}$ forms), physical (particle and pore size distribution, pore structure), hydrological (soil water retention, saturated and unsaturated hydraulic conductivity), mineralogical and micromorphological analyses were carried out for three soil profiles selected in two of the main head scarps.

The studied soils showed a substantial abrupt discontinuity in all the studied properties at the interface with a buried fine ash layer (namely, the $2 \mathrm{C}$ horizon), that was only marginally involved in the sliding surface of the landslide phenomena. When compared to the overlying horizons, $2 \mathrm{C}$ showed (i) fine grey ash that is almost pumice free, with the silt content increasing by $20 \%$; (ii) $k_{\mathrm{s}}$ values 1 order of magnitude lower; (iii) a pore distribution concentrated into small $(15-30 \mu \mathrm{m}$ modal class) pores characterised by a very low percolation threshold (approximately 15-25 $\mu \mathrm{m}$ ); (iv) the presence of expandable clay minerals; and (v) increasing $\mathrm{Na}$ content in the exchange complex. Most of these properties indicated that $2 \mathrm{C}$ was a lower permeability horizon compared to the overlying ones. Nevertheless, it was possible to assume this interface to be an impeding layer to vertical water fluxes only by the identification of a thin $(6.5 \mathrm{~mm})$ finely stratified ash layer, on top of $2 \mathrm{C}$, and of the hydromorphic features (e.g. $\mathrm{Fe} / \mathrm{Mn}$ concretions) within and on top of the layer. Although Mt. Vezzi's soil environment has many properties in common with those of other Campania debris-mudflows (e.g. high gradient, north-facing slope, similar forestry, and vol-
\end{abstract}

canic origin of the parent material), the results of this study suggest a more complex relationship between soil properties and landslides and emphasise the role of vertical discontinuities as noteworthy predisposing factors.

\section{Introduction}

The Italian territory is vulnerable from a hydraulic and geological standpoint, owing to its distinctive geological, geomorphological and climatic factors, along with anthropic pressures. Landslides are frequent and widespread (Guzzetti et al., 1994; Guzzetti and Tonelli, 2004) and the damage they cause is severe. In the last 50 years (1964-2013), all 20 Italian regions have suffered fatal events. Data from CNR-IRPI (Italian National Council of Research-Research Institute for Geo-Hydrological Protection), released by $\mathrm{La}$ Stampa (2014), show floods in 989 municipalities, which caused 1629 casualties (710 killed, 72 missing and 847 injured), and landslides in 1332 towns, which produced 3042 casualties (1297 killed, 15 missing and 1731 injured).

Campania is the region with the third-highest number of landslide events (363) in Italy. In the ecosystems of this region, the most dangerous types of landslide are debrismudflows, i.e. very rapid to extremely rapid flows of detritic and plastic materials with high water content (Hungr et al., 2001). One of the most catastrophic historical events occurred at Sarno on 5 and 6 May 1998: debris-mudflows detached from the slopes of Pizzo D'Alvano and extended $3-4 \mathrm{~km}$ into the surrounding lowlands, causing the loss of 161 human lives and severe destruction. In addition, other 
disastrous events struck the mountainous reliefs of this region before and after the Sarno event.

The soil properties and relationships between debrismudflows and soil types were investigated for 20 catastrophic landslides that occurred in Campania (Terribile et al., 2000, 2007). The results showed that the most catastrophic events generally occurred on high gradient, northfacing slopes. The soils developed on pyroclastic materials, covering the carbonatic reliefs of the Campania Apennines, and belonged to the Andosols group, generally the MolliVitric and Pachi-Vitric Andosols (IUSS Working Group WRB, 2014). In another study of the soils related to the Sarno landslides, Basile et al. (2003) found an increase in soil water storage, due to the occurrence of soil discontinuities (e.g. soil mantle cutting due to trackways), and demonstrated that landslide susceptibility is also strongly affected by human-induced disturbances to forestry ecosystems. Therefore, these studies concluded that the main factors affecting the susceptibility of these types of soils to landslides were (i) slope gradient, (ii) aspect of the slope, (iii) soil discontinuities, (iv) soil hydrological properties (i.e. water retention and hydraulic conductivity) and (v) andic properties.

Hence, when five debris-mudflows were triggered on 30 April 2006, on the northern slope of Mt. Vezzi on the island of Ischia, killing four people, an investigation to assess the presence of andic properties in Ischia's soils was carried out, because of the close similarities of the environments (volcanic), type of landslide (debris-mudflows) and aspect of the slope (northern) with those of other Campania landslides (Terribile et al., 2007). Thus, the principal aim of this work was to investigate the properties (chemical, physical, hydrological, mineralogical and micromorphological) of the soils at Mt. Vezzi to (i) define whether the soil properties may have had a role in causing these landslides, (ii) verify whether the relationship between andic properties and debris-mudflows, such as that found for the most catastrophic landslides that occurred in Campania, is also valid for Ischia; and (iii) carry out a detailed micro-scale investigation of the horizon that was marginally involved with the sliding surface, to understand the causes of the events that occurred.

\subsection{Events and geomorphological data related to the landslide area}

Five landslides (namely f1-f5, following Ascione et al., 2007) (Fig. 1a) occurred at 7-8 a.m. on 30 April 2006 along the northern slope of Mt. Vezzi. The source area is located in the uppermost Costa Ruscello hillslope in a narrow belt (between 315 and $345 \mathrm{~m}$ a.s.l.) close to Mt. Vezzi's summit and is characterised by a high slope gradient $\left(35-45^{\circ}\right)$ and variable morphology: $\mathrm{f} 1$ initiated at the outer rim of an access track, while f2-f5 started very close to the free face of Costa Ruscello's summit (Ascione et al., 2007; De Vita et al., 2007). In this study, only f 2 and $\mathrm{f} 3$ were examined. The landslides were classified by De Vita et al. (2007) as complex debris slides-debris flows (according to Cruden and Varnes, 1996). Mazzarella and De Luise (2009) reported a very low cumulative rainfall of $14 \mathrm{~mm}$ during the $24 \mathrm{~h}$ before the landslides were triggered, as measured by the nearest available meteorological station (Forio d'Ischia) (Fig. 1b). The station is located rather far $(6 \mathrm{~km})$ from Mt. Vezzi and at $150 \mathrm{~m}$ a.s.l. Nevertheless, remarkable evidences of water runoff and reliable witnesses indicated that the landslides were preceded by intense localised rainfall that was not detected by the Forio d'Ischia station.

\subsection{Geological and environmental setting}

The island of Ischia represents the emerged part of a large active volcanic complex rising to more than $1000 \mathrm{~m}$ a.s.l., located in the easternmost portion of the Naples city area (Fig. 1c). Together with the island of Procida and the Campi Flegrei caldera, Ischia constitutes the Phlegrean volcanic district (De Vita et al., 2010). Mt. Vezzi (392 m a.s.1.) is located in the south-eastern area of the island (Fig. 1b) and, together with Mt. Torrione (375 m a.s.1.), belongs to a group of relics of a major volcanic complex related to the second of the five volcanic phases recorded on the island (Rittmann and Gottini, 1980; Vezzoli, 1988, Civetta et al., 1991). The top of Mt. Vezzi consists of a lava dome (Di Nocera et al., 2007) covered by the Piano Liguori Formation, i.e. pyroclastic products of recent hydromagmatic explosive activity (about $5347-5807$ years BP, ${ }^{14} \mathrm{C}$ calibrated) (Orsi et al., 1996), which consists of trachytic ash and pumice layers. The dominant land use in Piano Liguori and the nearby surrounding slopes consists of vineyards, whereas chestnut coppice woodland characterises the high gradient northern slopes. The woodland appears poorly managed in the head scarps because of clear signs of unplanned cutting and evidence of anthropic disturbances, such as a dense trail network and fire traces on tree barks.

\section{Materials and methods}

The first survey on the head scarps of Ischia's landslides was conducted in the period just after the landslides (on 12 May 2006), when two shallow soil profiles were analysed (Vingiani and Terribile, 2007). However, a detailed pedological study was carried out only during the following summer, due to the wet state of the deep soil horizons, which limited digging. Soil profiles were studied in the main representative head scarps and were selected as representative pedons of each detachment area. Two (f2 and f3) of the five head scarps were studied (Fig. 1a). Two soil profiles (P1 and P2), approximately $3 \mathrm{~m}$ apart, were described and sampled in $\mathrm{f} 2$ and one (P3) in f3, following the guidelines of FAO (2006). Bulk and undisturbed soil samples were collected for chemical, physical (particle size distribution and hydraulic prop- 

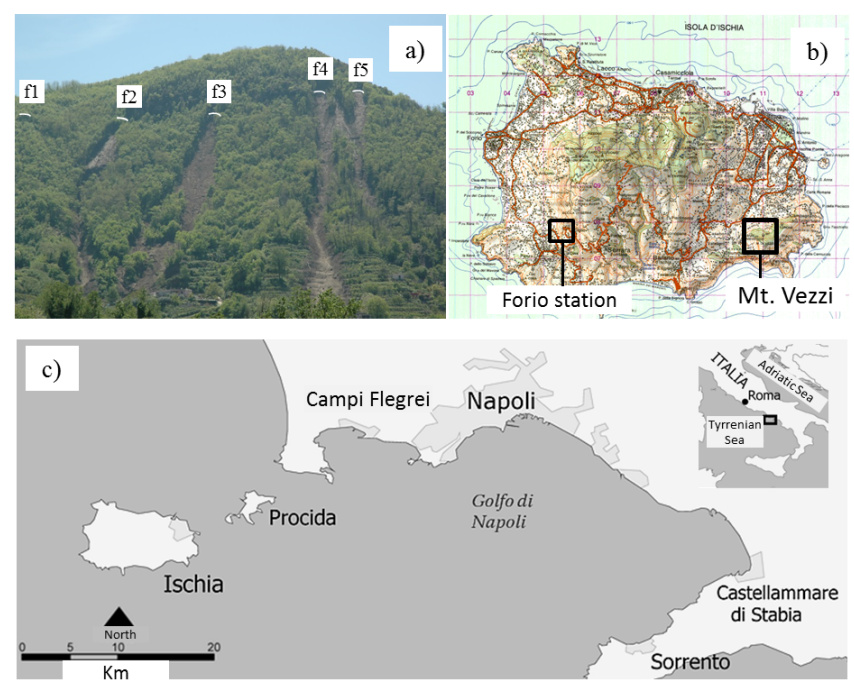

Figure 1. (a) Northern slope of Mt. Vezzi, showing both the positions and names (by Ascione et al., 2007) of the five head scarps; (b) topographic map of Ischia (1:50000 scale), showing the locations of Mt. Vezzi and the Forio station, (c) location of the island of Ischia ahead of the Golfo di Napoli (southern Italy).

erties), mineralogical, micromorphological and microtomographic analyses. The soils were classified using the WRB system (IUSS Working Group WRB, 2014). Moreover, two field sensitivity tests were used to estimate the soil's andic properties: (1) one test evaluates the thixotropy (smearing upon pressure) of moist, undisturbed soil samples by applying a simple pressure between fingers (Wells and Furkert, 1972). When allophanes (therefore andic properties) are present, the material becomes sensitive and suddenly shears under increasing pressure. The other test (2) evaluates the amount of non-crystalline (amorphous) material in the soil; the action of sodium fluoride $(\mathrm{NaF})$ upon non-crystalline soil material induces the release of $\mathrm{OH}^{-}$into the soil solution and increases the $\mathrm{pH}$ (Fields and Perrott, 1966).

\subsection{Chemical analysis}

The bulk soil samples were air-dried and sieved at $2 \mathrm{~mm}$. The percentage of coarse fragments $(>2 \mathrm{~mm}$ ) was calculated on a weight basis. Chemical analyses were carried out on the fine earth fraction, according to the Soil Survey Laboratory Methods Manual (SSS, 2014). Soil pH was determined potentiometrically from soil- $\mathrm{H}_{2} \mathrm{O}(1: 2.5$ ratio $)$ and soil solution $(\mathrm{KCl} 1 \mathrm{M}$ and $\mathrm{NaF} 1 \mathrm{M}, 1: 2.5$ and $1: 5$ ratios, respectively) suspensions. Organic carbon (OC) content was determined following Walkley and Black's (1934) procedure and the cation exchange capacity (CEC) was determined according to Mehlich (1938), with barium chloridetriethanolamine buffered at $\mathrm{pH} 8.2$, and exchangeable cations $\left(\mathrm{Ca}^{2+}, \mathrm{Mg}^{2+}, \mathrm{Na}^{+}, \mathrm{K}^{+}\right)$were measured by the ICP-AES Varian Liberty model 150 . Phosphate retention was deter- mined according to Blakemore et al. (1987) and electrical conductivity (EC) was measured from soil- $\mathrm{H}_{2} \mathrm{O}(1: 5$ ratio) suspensions. The sodium adsorption ratio (SAR) was calculated (Lesch and Suarez, 2009) as the square root of the ratio of the measured exchangeable sodium $\left(\mathrm{Na}^{+}\right)$to calcium + magnesium $\left(\mathrm{Ca}^{2+}+\mathrm{Mg}^{2+}\right)$, divided by two, and the exchangeable sodium percentage (ESP) was calculated as the percentage ratio of the $\mathrm{Na}^{+}$content to the CEC.

Due to the volcanic origin of the parent material, specific analyses were also required to assess the presence of andic properties. Selective extraction procedures were applied to the soil samples, and the different Al, Fe and Si forms were determined. The acid ammonium oxalate-extractable forms $\left(\mathrm{Al}_{\mathrm{o}}, \mathrm{Fe}_{\mathrm{o}}\right.$ and $\left.\mathrm{Si}_{\mathrm{o}}\right)$ were obtained according to Schwertmann (1964) and Blakemore et al. (1987), and the Na-dithionite citrate bicarbonate (DCB)-extractable components $\left(\mathrm{Al}_{\mathrm{d}}, \mathrm{Fe}_{\mathrm{d}}\right.$ and $\mathrm{Si}_{\mathrm{d}}$ ), also called the total "free iron oxides", were obtained by the Mehra and Jackson (1960) procedure. The Napyrophosphate-extractable complexes $\left(\mathrm{Al}_{\mathrm{p}}\right.$ and $\left.\mathrm{Fe}_{\mathrm{p}}\right)$ were obtained according to Bascomb (1968). The concentration of the elements was then measured using the ICP AES Varian Liberty model 150 . The allophane and ferrihydrite contents were calculated using Parfitt (Parfitt and Wilson, 1985; Parfitt, 1990) and Childs' (1985) formulae, respectively.

\subsection{Hydrological analysis}

Hydrological analyses were carried out on undisturbed soil samples (diameter $86 \mathrm{~mm}$, height $150 \mathrm{~mm}$ ) collected from selected horizons along soil profiles $\mathrm{P} 2\left(\mathrm{Bw}_{1}, \mathrm{Bw}_{2}, \mathrm{Bw}_{4}\right.$, $2 \mathrm{CB}, 2 \mathrm{C})$ and $\mathrm{P} 3\left(\mathrm{Bw}_{4}, 2 \mathrm{C}, 3 \mathrm{Btb}\right)$. The saturated hydraulic conductivity, $k_{\mathrm{s}}$, was measured using a constant head permeameter (Reynolds and Elrick, 2003). The soil water retention $\theta(h)$, which is the relationship between the water content $\theta$ and water pressure head $h$, and the hydraulic conductivity $k(\theta)$, which is the relationship between the hydraulic conductivity $k$ and water content $\theta$, were both determined by applying the evaporation method (Arya, 2002). The undisturbed soil samples were slowly saturated from the bottom. Three tensiometers were installed at three different depths in the samples and placed on a load cell; starting from saturation and during 1-dimensional transient upward flow, the pressure head and weight of the sample were automatically recorded at these depths until air was observed in the circuit of the uppermost tensiometer. Afterwards, the soil sample was dismantled and placed in an oven at $105^{\circ} \mathrm{C}$ for $24 \mathrm{~h}$ to determine the water content from the weight data set. An iterative method was applied to obtain the $\theta(h)$ relationship (Basile et al., 2012). The unsaturated hydraulic conductivity curve was obtained by applying the method proposed by Watson (1966). Details of the calculus procedure can be found in Bonfante et al. (2010). 


\subsection{Physical and microtomographic analyses}

The particle size distribution (PSD) of soil samples was determined after dispersion with Na-hexametaphosphate and the measurements were carried out using the laser diffraction technique with a Malvern Mastersizer 2000 system (Glendon and Dani, 2002).

X-ray microtomography was performed to reconstruct 3D images of the inner structure of the soil samples collected from three subsurface contiguous horizons identified in soil profile P2. The SKYSCAN 1172 desktop system (www.skyscan.be), which is based on a microfocus cone beam X-ray source, was used and an optimised inverse radon transform (Kak and Slaney, 1988) was applied to the Xray attenuation coefficient data set for image reconstruction. Then, the "successive opening" image analysis algorithm (e.g. Serra, 1982; Horgan, 1998) was applied to the reconstructed 3-D images to obtain a pore size distribution (PoSD) consisting of the pore space classification made according to the wall spacing. Finally, the procedure of Lantuejoul and Maisonneuve (1984) was applied to calculate the percolation curves and evaluate the connectivity of the pore space.

The inter-aggregate PoSD of each horizon was calculated by scanning undisturbed soil samples collected with polymethyl methacrylate (PMMA) cylinders that are $3.4 \mathrm{~cm}$ in height and diameter, then a $3.5 \mathrm{~cm}^{3}$ cubic region of interest (ROI) was reconstructed at $30 \mu \mathrm{m}$ pixel size (image resolution). The intra-aggregate 3-D pore structure was reconstructed and analysed for a $3.5 \mathrm{~mm}^{3} \mathrm{ROI}$ at $1.5 \mu \mathrm{m}$ image resolution by separately scanning two selected aggregates from the bulk samples.

In addition, a pore size distribution was derived from the hydrological analysis. Specifically, the scale of the soil water pressure head on the axis of the soil water retention curve can be replaced by that of the diameter of the capillaries according to the capillarity law $|h| \approx 0.3 / d$ for length units in $\mathrm{cm}$ (Jurin, 1718). This procedure supplies the cumulative pore size distribution curve. The derivative of this curve is the curve of the pore size density distribution. Such a schematisation, which assumes that a simple conceptual model of the soil porous system as a bundle of parallel capillaries to be correct, leads to the derivation of the "equivalent" pore size distribution. In this manner, the equivalent diameters are those of the bundle of capillary tubes, which behave, in functional terms, as the soil sample.

\subsection{Mineralogical and micromorphological analyses}

Mineralogical analyses were carried out by means of Xray diffractometry (XRD) on sand, silt and clay fractions. The samples were dispersed with Na-hexametaphosphate and separated into different sizes by means of sieving, for the sand and silt fractions, and by centrifuge, for the clay fraction. The clay fraction was saturated using $\mathrm{CaCl}_{2}$ and washed with water and ethanol, until the chlorides were removed. The mineralogical spectra were acquired with a Rigaku Geigerflex D/Max IIIC, with CuKa radiation and $\mathrm{Ni}$-filtered, at $35 \mathrm{~kW}$ and $35 \mathrm{~mA}$. Powder samples of sand $(2 \mathrm{~mm}-50 \mu \mathrm{m})$ and silt $(50-2 \mu \mathrm{m})$ were analysed to detect the primary and secondary minerals, while clays $(<2 \mu \mathrm{m})$ were analysed on oriented mounts.

Undisturbed samples collected by means of Kubiena boxes for micromorphological studies were impregnated with crystic resin, and large $(15 \mathrm{~cm} \times 7.5 \mathrm{~cm})$ thin sections were produced using FitzPatrick's methodology (1984, 1993). The micromorphological description followed the terminology used by FitzPatrick (1993).

\section{Results}

\subsection{Soil morphology}

All the studied soils (Table 1) were very deep and characterised by the following sequence: shallow (approximately $5 \mathrm{~cm}$ ) brownish surface horizons (A), dark yellowish to olive brown $\mathrm{Bw}$ horizons, and greyish brown to light brownish grey $2 \mathrm{C}$ horizons. Both field tests for the identification of andic properties were negative, showing the absence of thixotropy and andic properties. Carbonates were absent from all the soil samples. The soil structure was generally weakly to moderately developed in all the A and $\mathrm{Bw}$ horizons (see Table 1) but abruptly changed to massive structure in 2C. Just after the landslide events, the soil horizons also showed very different moisture statuses: the A and Bw horizons were slightly moist, whereas the massive $2 \mathrm{C}$ was wet, which limited digging to a depth of $100 \mathrm{~cm}$. The above described $2 \mathrm{C}$ horizon was found in all the studied soil profiles and was only marginally involved with the sliding surface of the recorded landslides (De Vita et al., 2007). In P1 and P3, a buried yellowish red B horizon (named 3Btb in P1 and P3) with a moderately developed structure was found below $2 \mathrm{C}$. Very few to few roots were found in the A and Bw horizons, but they were always absent from $2 \mathrm{C}$ and $3 \mathrm{Btb}$.

\subsection{Main chemical properties}

The results of the chemical analyses showed a large accumulation of OC (46.1-71.3 $\mathrm{g} \mathrm{kg}^{-1}$ ) (Table 2) in all the A horizons. As expected, the OC decreased rapidly with depth ( $\mathrm{Bw}_{1}$ horizons: $12.3-6.0 \mathrm{~g} \mathrm{~kg}^{-1} ; 2 \mathrm{C}$ horizons: $0.8-$ $1.2 \mathrm{~g} \mathrm{~kg}^{-1}$ ). A similar trend was followed by the CEC, whose highest values - as expected - were found in the A horizons. The soils had a generally neutral reaction $\left(\mathrm{pH}_{\mathrm{H}_{2} \mathrm{O}}\right)$, with the $\mathrm{pH}$ increasing weakly with depth until the $2 \mathrm{C}$ horizon (Table 2). $\mathrm{pH}_{\mathrm{KCl}}$ was $1-2.5$ units lower than $\mathrm{pH}_{\mathrm{H}_{2} \mathrm{O}}$, which suggested a potential exchangeable acidity (due to $\mathrm{H}^{+}$ and $\mathrm{Al}^{3+}$ ions) that was particularly high for the $2 \mathrm{C}$ horizons (values between 2.0 and 2.5). Although the exchangeable complex was dominated by $\mathrm{Ca}^{2+}$, high $\mathrm{Na}^{+}+\mathrm{Mg}^{2+}$ contents $(40-65 \%)$ were measured in the deepest horizons 
Table 1. Field morphology description of the studied soil profiles.

\begin{tabular}{|c|c|c|c|c|c|c|c|}
\hline Profile & Horizon & Depth $(\mathrm{cm})$ & Moistness & Colour (moist) & Structure & Roots & Rock fragments \\
\hline \multirow{6}{*}{$\mathrm{P} 1$} & A & $0-5$ & $\mathrm{sm}$ & $10 Y R 3 / 2$ & we to mo fi GR & vf F & f A \\
\hline & Bw1 & $5-18$ & $\mathrm{sm}$ & 10YR 4/4 & we to mo me SB & f V & $\mathrm{m} \mathrm{A}$ \\
\hline & Bw2 & $18-55$ & $\mathrm{~m}$ & $2.5 \mathrm{Y} 4 / 3$ & we to mo SB & vf F & $\mathrm{m} \mathrm{M}$ \\
\hline & $2 \mathrm{CB}$ & $55-70$ & $\mathrm{sm}$ & $2.5 \mathrm{Y} 4 / 3$ & we SB me to MA & $\mathrm{N}$ & $\mathrm{m} \mathrm{M}$ \\
\hline & $2 \mathrm{C}$ & $70 / 90-110 / 120$ & $\mathrm{sm}$ & $2.5 Y 5 / 2$ & MA & $\mathrm{N}$ & f V \\
\hline & $3 \mathrm{Btb}$ & $110 / 120-170+$ & $\mathrm{sm}$ & $10 Y R$ 4/4 & mo me SB & $\mathrm{N}$ & $\mathrm{fV}$ \\
\hline \multirow[t]{7}{*}{$\mathrm{P} 2$} & A & $0-5$ & $\mathrm{sm}$ & 10YR $2 / 2$ & we fi GR & vf F & f F \\
\hline & Bw1 & $5-50$ & $\mathrm{sm}$ & $10 Y R$ 4/4 & we me SB & f V & $\mathrm{fC}$ \\
\hline & Bw2 & $50-90 / 110$ & $\mathrm{sm}$ & 10YR 4/4 & we co SB & $\mathrm{fF}$ & $\mathrm{m} \mathrm{A}$ \\
\hline & Bw3 & $110-130 / 140$ & $\mathrm{sm}$ & $2.5 \mathrm{Y} 4 / 4$ & we co SB & $\mathrm{c} \mathrm{V}$ & $\mathrm{fm} A$ \\
\hline & Bw4 & $140-170$ & $\mathrm{sm}$ & $2.5 \mathrm{Y} 4 / 3$ & we me SB & f V & $\mathrm{m} \mathrm{M}$ \\
\hline & $2 \mathrm{CB}$ & $170-180 / 205$ & $\mathrm{sm}$ & $2.5 \mathrm{Y} 4 / 3$ & we SB me to MA & f V & f V \\
\hline & $2 \mathrm{C}$ & $205-215+$ & $\mathrm{sm}$ & $2.5 Y 5 / 2$ & MA & $\mathrm{N}$ & $\mathrm{N}$ \\
\hline \multirow[t]{7}{*}{ P3 } & $\mathrm{A}$ & $0-5$ & $\mathrm{sm}$ & $10 Y R 2 / 2$ & mo fi GR & vf F & $\mathrm{mF}$ \\
\hline & Bw1 & $15-50$ & $\mathrm{sm}$ & $10 Y R 4 / 4$ & we me SB & f F & $\mathrm{fm} \mathrm{C}$ \\
\hline & Bw2 & $50-85$ & $\mathrm{sm}$ & $10 \mathrm{YR} 4 / 4$ & we co SB & vf V & c A \\
\hline & Bw3 & $85-135$ & $\mathrm{sm}$ & $2.5 \mathrm{Y} 4 / 3$ & we me SB & vf V & $\mathrm{m} \mathrm{M}$ \\
\hline & Bw4 & $135-190$ & $\mathrm{sm}$ & $2.5 \mathrm{Y} 4 / 3$ & we me SB & vf F & $\mathrm{m} \mathrm{M}$ \\
\hline & $2 \mathrm{C}$ & $190-220$ & $\mathrm{sm}$ & $2.5 \mathrm{Y} 6 / 2$ & we SB me to MA & $\mathrm{N}$ & $\mathrm{N}$ \\
\hline & $3 \mathrm{Btb}$ & $220-260+$ & $\mathrm{sm}$ & 10YR 5/4 & mo me SB & $\mathrm{N}$ & $\mathrm{N}$ \\
\hline
\end{tabular}

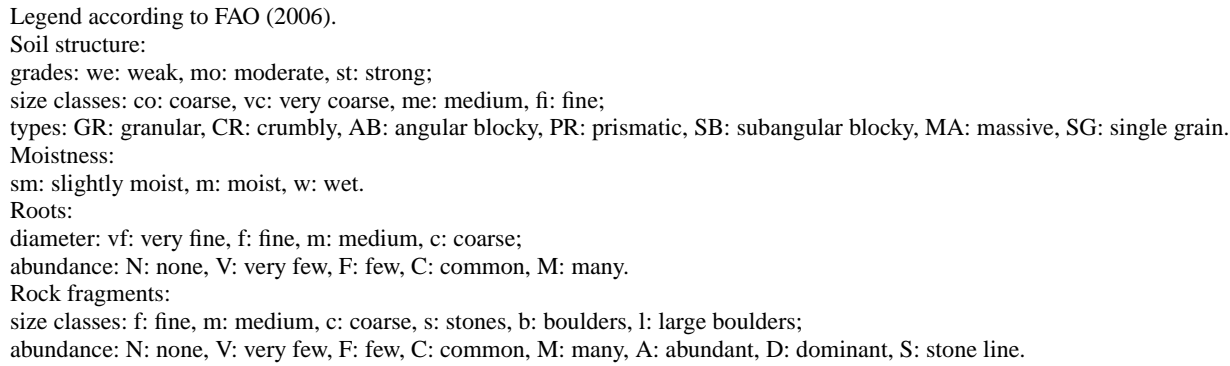

of the three profiles, which showed a calculated exchangeable sodium percentage (ESP) that was generally higher than $15 \%$. Data from the selective extraction procedures showed generally low $\% \mathrm{Al}_{\mathrm{o}}+0.5 \mathrm{Fe}_{\mathrm{o}}$, ranging from 0.1 to 0.7 , and low allophane $(0.9-2.6 \%)$ and ferrihydrite $(0.1-0.6 \%)$ contents (Table 3) for all of the soils. The low $\% \mathrm{Al}_{\mathrm{o}}+0.5 \mathrm{Fe}_{\mathrm{o}}$, which is associated with low phosphate retention - Pret (2-35\%) (Table 3), indicated that these soils generally did not satisfy the requirements for Andosol classification (IUSS Working Group WRB, 2014), except for soil profile P1, which falls into the Andosols region around the boundary with the Cambisols. Therefore, these soils were classified as follows: P1,Vitric Andosol (loamic, novic, sodic); P2, Sodic Cambisol (loamic, tephric) and P3, Sodic Cambisol (loamic, colluvic, novic, tephric). Moreover, the Na-pyrophosphateextractable forms ( $\mathrm{Al}$ and $\mathrm{Fe}$-humus complexes) were always negligible, according to the very low $\mathrm{Al}_{\mathrm{p}} / \mathrm{Al}_{\mathrm{o}}$ ratios $(<0.4)$, even in the most rich OC $\left(71.3 \mathrm{~g} \mathrm{~kg}^{-1}\right)$ horizon. The calculated $\mathrm{Fe}_{\mathrm{o}} / \mathrm{Fe}_{\mathrm{d}}$ ratios showed values generally decreasing with depth (from 0.7 to 0.1 ).

\subsection{Physical properties}

\subsubsection{Particle size distribution (PSD)}

The rock fragment $(d>2 \mathrm{~mm})$ fraction showed the highest content of pumices in the A and B horizons (Table 4). Medium size $(5-20 \mathrm{~mm})$ pumices ranged from few (3-4\%) to many $(18-22 \%)$ in the A and B horizons, whereas only few (approximately $1 \%$ or less) and very fine $(2-5 \mathrm{~mm}$ ) pumices were found in all the $2 \mathrm{C}$ horizons and in $3 \mathrm{Btb}$ in both P1 and P3 (Table 4). The A horizons and most of the $\mathrm{Bw}$ horizons were sandy loam; the former was coarser than the latter. The $\mathrm{Bw}, 2 \mathrm{CB}$ and $2 \mathrm{C}$ horizons were silty loam (Table 4), according to the higher silt content (greater than $50 \%$ ). All the horizons showed a more or less pronounced bimodal PSD (Fig. 2). Generally, the A and Bw horizons (Fig. 2a and c) exhibited a stronger bimodal distribution of soil particles, one population having a peak at diameters of approximately $30-50 \mu \mathrm{m}$ and another at $600-900 \mu \mathrm{m}$. The PSD of the $2 \mathrm{C}$ horizons (Fig. $2 \mathrm{~b}$ and d) was revealed to be very different, with a much less pronounced bimodal distri- 
Table 2. Soil chemical properties.

\begin{tabular}{|c|c|c|c|c|c|c|c|c|c|c|c|c|c|c|c|}
\hline \multirow[t]{2}{*}{ Profile } & \multirow[t]{2}{*}{ Horizon } & \multirow{2}{*}{$\begin{array}{c}\mathrm{OC} \\
\mathrm{g} \mathrm{kg}^{-1}\end{array}$} & \multicolumn{3}{|c|}{$\mathrm{pH}$} & \multirow[t]{2}{*}{$\Delta \mathrm{pH}$} & \multirow{2}{*}{$\begin{array}{c}\mathrm{CEC} \\
\mathrm{cmol}^{(+)} \mathrm{Kg}^{-1} \\
\end{array}$} & \multirow[t]{2}{*}{$\mathrm{Na}$} & \multirow[t]{2}{*}{$\mathrm{Ca}$} & $\mathrm{Mg}$ & \multirow[t]{2}{*}{$\mathrm{K}$} & \multirow[t]{2}{*}{$\mathrm{BS}$} & \multirow[t]{2}{*}{ ESP } & \multirow{2}{*}{$\begin{array}{c}\mathrm{EC} \\
\mu \mathrm{Scm}^{-1}\end{array}$} & \multirow[t]{2}{*}{ SAR } \\
\hline & & & $\mathrm{H}_{2} \mathrm{O}$ & $\mathrm{KCl}$ & $\mathrm{NaF}$ & & & & & $\%$ & & & & & \\
\hline \multirow[t]{6}{*}{$\mathrm{P} 1$} & A & 46.1 & 6.9 & 5.8 & 9.5 & 1.1 & 20.7 & 5.8 & 64.1 & 21.4 & 8.7 & 100 & 5.8 & n.d. & 0.4 \\
\hline & Bw1 & 12.3 & 6.8 & 5.4 & 10.3 & 1.4 & 15.1 & 12.1 & 38.4 & 24.2 & 25.3 & 66 & 7.9 & n.d. & 0.7 \\
\hline & Bw2 & 4.1 & 7.0 & 4.9 & 9.4 & 2.1 & 13.5 & 10.4 & 19.3 & 47.4 & 23.0 & 100 & 10.4 & n.d. & 0.7 \\
\hline & $2 \mathrm{CB}$ & 3.1 & 7.4 & 5.2 & 9.2 & 2.2 & 14.0 & 17.1 & 33.6 & 22.9 & 26.4 & 100 & 17.1 & 75.8 & 1.2 \\
\hline & $2 \mathrm{C}$ & 0.8 & 7.6 & 5.1 & 8.8 & 2.5 & 10.5 & 22.9 & 30.5 & 24.8 & 21.9 & 100 & 22.9 & 50.7 & 1.4 \\
\hline & 3Btb & 0.9 & 7.4 & 5.0 & 9.0 & 2.4 & 15.6 & 24.0 & 32.0 & 27.0 & 17.0 & 100 & 63.0 & 102.2 & 1.4 \\
\hline \multirow[t]{7}{*}{$\mathrm{P} 2$} & $\mathrm{~A}$ & 71.3 & 6.7 & 6.0 & 9.5 & 0.7 & 36.8 & 3.3 & 73.1 & 19.3 & 4.3 & 100 & 3.3 & n.d. & 0.3 \\
\hline & Bw1 & 5.9 & 7.1 & 5.7 & 9.9 & 1.4 & 10.7 & 10.0 & 46.0 & 23.0 & 21.0 & 94 & 9.3 & n.d. & 0.5 \\
\hline & Bw2 & 5.6 & 7.4 & 5.9 & 10.1 & 1.5 & 9.4 & 12.9 & 48.2 & 20.0 & 18.8 & 90 & 11.7 & n.d. & 0.6 \\
\hline & Bw3 & 4.7 & 7.1 & 5.1 & 10.0 & 2.0 & 13.0 & 14.5 & 46.2 & 14.5 & 24.8 & 90 & 13.1 & n.d. & 0.9 \\
\hline & Bw4 & 2.7 & 7.3 & 5.4 & 9.7 & 1.9 & 10.8 & 17.8 & 43.9 & 13.1 & 25.2 & 100 & 17.6 & 73.6 & 1.1 \\
\hline & $2 \mathrm{CB}$ & 1.3 & 7.2 & 5.0 & 9.5 & 2.2 & 12.4 & 18.5 & 34.7 & 23.4 & 23.4 & 100 & 18.5 & 59.6 & 1.2 \\
\hline & $2 \mathrm{C}$ & 1.2 & 7.3 & 4.8 & 9.0 & 2.5 & 9.9 & 34.8 & 4.5 & 30.3 & 30.3 & 90 & 31.3 & 64.8 & 2.5 \\
\hline \multirow[t]{7}{*}{ P3 } & A & 49.4 & 6.7 & 6.0 & 9.6 & 0.7 & 28.6 & 4.6 & 62.8 & 21.8 & 10.9 & 100 & 4.5 & n.d. & 0.4 \\
\hline & Bw1 & 6.0 & 6.0 & 4.2 & 9.9 & 1.8 & 16.2 & 13.0 & 42.7 & 23.7 & 20.6 & 80 & 10.5 & n.d. & 0.8 \\
\hline & Bw2 & 2.9 & 6.9 & 5.0 & 9.7 & 1.9 & 15.1 & 12.7 & 45.1 & 22.5 & 19.7 & 94 & 11.9 & n.d. & 0.8 \\
\hline & Bw3 & 3.6 & 7.1 & 5.2 & 9.7 & 1.9 & 10.7 & 13.5 & 39.4 & 26.0 & 21.2 & 96 & 13.1 & n.d. & 0.8 \\
\hline & Bw4 & 2.3 & 7.2 & 5.2 & 9.4 & 2.0 & 8.5 & 17.6 & 34.1 & 28.2 & 20.0 & 100 & 17.6 & 58.7 & 0.9 \\
\hline & $2 \mathrm{C}$ & 1.2 & 7.2 & 5.2 & 9.5 & 2.0 & 11.6 & 17.1 & 29.9 & 35.9 & 17.1 & 100 & 17.2 & 63.3 & 1.0 \\
\hline & $3 \mathrm{Btb}$ & 1.1 & 7.1 & 5.2 & 9.2 & 1.9 & 15.2 & 19.1 & 35.5 & 27.6 & 17.8 & 100 & 19.1 & 127.1 & 1.3 \\
\hline
\end{tabular}

BS: base saturation calculated as $\sum$ bases $\cdot 100 / \mathrm{CEC}$. ESP: exchangeable sodium percentage. SAR: sodium adsorption ratio. $\Delta \mathrm{pH}$ : calculated as the difference between $\mathrm{pH} \mathrm{H}_{2} \mathrm{O}$ and $\mathrm{pH} \mathrm{KCl}$.

Table 3. Selectively dissolved elements (Al, Fe, Si) measured by ICP AES.

\begin{tabular}{|c|c|c|c|c|c|c|c|c|c|c|c|c|}
\hline \multirow[t]{2}{*}{ Profile } & \multirow[t]{2}{*}{ Horizon } & $\mathrm{Al}_{\mathrm{O}}$ & $\mathrm{Fe}_{\mathrm{o}}$ & $\mathrm{Si}_{\mathrm{o}}$ & $\mathrm{Al}_{\mathrm{p}}$ & $\mathrm{Fe}_{\mathrm{d}}$ & $\mathrm{Al}_{\mathrm{o}}+0.5 \mathrm{Fe}_{\mathrm{o}}$ & Pret & \multirow[t]{2}{*}{ Alp / Alo } & \multirow[t]{2}{*}{$\mathrm{Fe}_{\mathrm{o}} / \mathrm{Fe}_{\mathrm{d}}$} & Allophane & Ferrihydrite \\
\hline & & & & $\mathrm{g} \mathrm{kg}^{-1}$ & & & $\%$ & & & & \multicolumn{2}{|c|}{$\%$} \\
\hline \multirow[t]{6}{*}{$\mathrm{P} 1$} & $\mathrm{~A}$ & 2.8 & 2.3 & 3.1 & 0.4 & 3.8 & 0.4 & 25 & 0.2 & 0.61 & 1.6 & 0.4 \\
\hline & Bw1 & 5.2 & 3.5 & 4.9 & 0.5 & 5.0 & 0.7 & 34 & 0.1 & 0.69 & 2.6 & 0.6 \\
\hline & Bw2 & 2.0 & 1.8 & 2.7 & 0.1 & 4.6 & 0.3 & 19 & 0.1 & 0.38 & 1.4 & 0.3 \\
\hline & $2 \mathrm{CB}$ & 1.7 & 1.2 & 2.6 & 0.1 & 4.5 & 0.2 & 16 & 0.0 & 0.27 & 1.3 & 0.2 \\
\hline & $2 \mathrm{C}$ & 0.5 & 0.3 & 1.9 & 0.1 & 1.9 & 0.1 & 2 & 0.3 & 0.17 & 0.8 & 0.1 \\
\hline & $3 \mathrm{Btb}$ & n.d. & n.d. & n.d. & n.d. & n.d. & n.d. & n.d. & n.d. & n.d. & n.d. & n.d. \\
\hline \multirow[t]{7}{*}{$\mathrm{P} 2$} & A & 3.5 & 2.5 & 3.6 & 0.7 & 3.9 & 0.5 & 32 & 0.2 & 0.65 & 1.8 & 0.4 \\
\hline & Bw1 & 3.3 & 2.0 & 4.6 & 0.1 & 3.5 & 0.4 & 22 & 0.0 & 0.58 & 2.3 & 0.3 \\
\hline & Bw2 & 3.9 & 1.8 & 5.0 & 0.1 & 3.3 & 0.5 & 20 & 0.0 & 0.54 & 2.6 & 0.3 \\
\hline & Bw3 & 1.8 & 1.5 & 2.5 & 0.1 & 3.8 & 0.3 & 17 & 0.0 & 0.40 & 1.3 & 0.3 \\
\hline & Bw4 & 1.6 & 1.0 & 2.4 & 0.0 & 3.7 & 0.2 & 15 & 0.0 & 0.27 & 1.2 & 0.2 \\
\hline & $2 \mathrm{CB}$ & 0.8 & 0.4 & 2.2 & 0.2 & 2.6 & 0.1 & 8 & 0.2 & 0.17 & 1.0 & 0.1 \\
\hline & $2 \mathrm{C}$ & 0.5 & 0.3 & 2.0 & 0.2 & 2.2 & 0.1 & 4 & 0.4 & 0.15 & 0.9 & 0.1 \\
\hline \multirow[t]{7}{*}{ P3 } & A & 3.1 & 2.0 & 3.4 & 0.3 & 4.3 & 0.4 & 27 & 0.1 & 0.47 & 1.8 & 0.3 \\
\hline & Bw1 & 2.2 & 1.2 & 2.8 & 0.1 & 4.3 & 0.3 & 21 & 0.1 & 0.27 & 1.4 & 0.2 \\
\hline & Bw2 & 2.2 & 1.0 & 3.0 & 0.0 & 4.1 & 0.3 & 18 & 0.0 & 0.23 & 1.5 & 0.2 \\
\hline & Bw3 & 1.3 & 0.8 & 2.5 & 0.1 & 3.6 & 0.2 & 12 & 0.0 & 0.23 & 1.2 & 0.1 \\
\hline & Bw4 & 0.7 & 0.5 & 2.1 & 0.1 & 2.5 & 0.1 & 8 & 0.1 & 0.19 & 1.0 & 0.1 \\
\hline & $2 \mathrm{C}$ & 0.6 & 0.4 & 2.2 & 0.1 & 2.2 & 0.1 & 5 & 0.1 & 0.18 & 1.0 & 0.1 \\
\hline & 3Btb & 0.8 & 0.4 & 2.2 & 0.3 & 3.1 & 0.1 & 9 & 0.3 & 0.13 & 1.0 & 0.1 \\
\hline
\end{tabular}

$\mathrm{Al}_{\mathrm{o}}, \mathrm{Fe}_{\mathrm{o}}, \mathrm{Si}_{\mathrm{o}}$ : ammonium oxalate-extractable aluminium, iron and silicium. $\mathrm{Al}_{\mathrm{p}}$ : Na-pyrophosphate-extractable aluminium. $\mathrm{Fe}_{\mathrm{d}}$ : Na-dithinite citrate-bicarbonate-extractable iron.

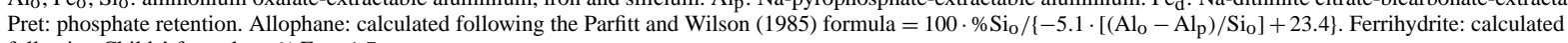
following Childs' formula $=\% \mathrm{Fe}_{\mathrm{o}} \cdot 1.7$.

bution, or an overall unimodal distribution, in which the most abundant population had a diameter of approximately $30 \mu \mathrm{m}$.
The PSD of $\mathrm{Bw}_{4}$ showed an intermediate behaviour between the $\mathrm{Bw}$ series and the underlying $2 \mathrm{C}$ horizons. 
Table 4. Particle size distribution (PSD) and saturated hydraulic conductivity $\left(k_{\mathrm{s}}\right)$.

\begin{tabular}{|c|c|c|c|c|c|c|c|c|}
\hline \multirow[t]{2}{*}{ Profile } & \multirow[t]{2}{*}{ Horizon } & \multirow[t]{2}{*}{ Sand } & \multirow[t]{2}{*}{ Silt } & \multirow{2}{*}{$\begin{array}{r}\text { Clay } \\
\%\end{array}$} & \multirow[t]{2}{*}{${ }^{*}$ Rock fragments } & \multirow[t]{2}{*}{ Textural classes } & \multicolumn{2}{|c|}{$k_{\mathrm{s}}$} \\
\hline & & & & & & & $\mathrm{cmh}^{-1}$ & $\mathrm{~cm} \mathrm{~s}^{-1}$ \\
\hline \multirow[t]{6}{*}{ P1 } & A & 57.8 & 39.0 & 3.2 & 16.0 & SL & & \\
\hline & Bw1 & 49.0 & 45.4 & 5.7 & 13.4 & SL & & \\
\hline & Bw2 & 49.3 & 44.8 & 5.9 & 6.2 & SL & & \\
\hline & $2 \mathrm{CB}$ & 35.5 & 55.8 & 8.6 & 20.3 & SiL & & \\
\hline & $2 \mathrm{C}$ & 36.5 & 56.6 & 6.9 & 0.9 & SiL & & \\
\hline & $3 \mathrm{Btb}$ & n.d. & n.d. & n.d. & n.d. & & & \\
\hline \multirow[t]{7}{*}{$\mathrm{P} 2$} & A & 57.7 & 39.9 & 2.4 & 3.1 & SL & & \\
\hline & Bw1 & 53.8 & 40.9 & 5.2 & 11.1 & SL & $1.03 \times 10^{2}$ & $2.86 \times 10^{-2}$ \\
\hline & Bw2 & 55.3 & 39.7 & 5.0 & 25.5 & SL & $1.35 \times 10^{2}$ & $3.75 \times 10^{-2}$ \\
\hline & Bw3 & 43.9 & 50.2 & 5.9 & 8.9 & SL & & \\
\hline & Bw4 & 36.1 & 54.5 & 9.4 & 4.2 & SiL & $8.07 \times 10^{1}$ & $2.24 \times 10^{-2}$ \\
\hline & $2 \mathrm{CB}$ & 28.4 & 63.9 & 7.7 & 1.0 & SiL & $2.33 \times 10^{1}$ & $6.47 \times 10^{-3}$ \\
\hline & $2 \mathrm{C}$ & 24.6 & 68.8 & 6.6 & 0.1 & SiL & $5.50 \times 10^{0}$ & $1.53 \times 10^{-3}$ \\
\hline \multirow[t]{7}{*}{ P3 } & A & 50.7 & 45.8 & 3.5 & 8.0 & SL & & \\
\hline & Bw1 & 51.0 & 43.1 & 5.9 & 20.9 & SL & & \\
\hline & Bw2 & 46.7 & 47.3 & 6.1 & 10.5 & SL & & \\
\hline & Bw3 & 41.3 & 50.6 & 8.1 & 11.1 & SiL & & \\
\hline & Bw4 & 48.5 & 44.7 & 6.9 & 8.0 & SL & $2.00 \times 10^{2}$ & $5.56 \times 10^{-2}$ \\
\hline & $2 \mathrm{C}$ & 33.1 & 59.2 & 7.7 & 1.3 & SiL & $1.06 \times 10^{1}$ & $2.94 \times 10^{-3}$ \\
\hline & $3 \mathrm{Btb}$ & 38.9 & 55.2 & 5.9 & 0.7 & SiL & $2.40 \times 10^{1}$ & $6.67 \times 10^{-3}$ \\
\hline
\end{tabular}

* values are percentages of the total bulk soil; n.d.: not determined.
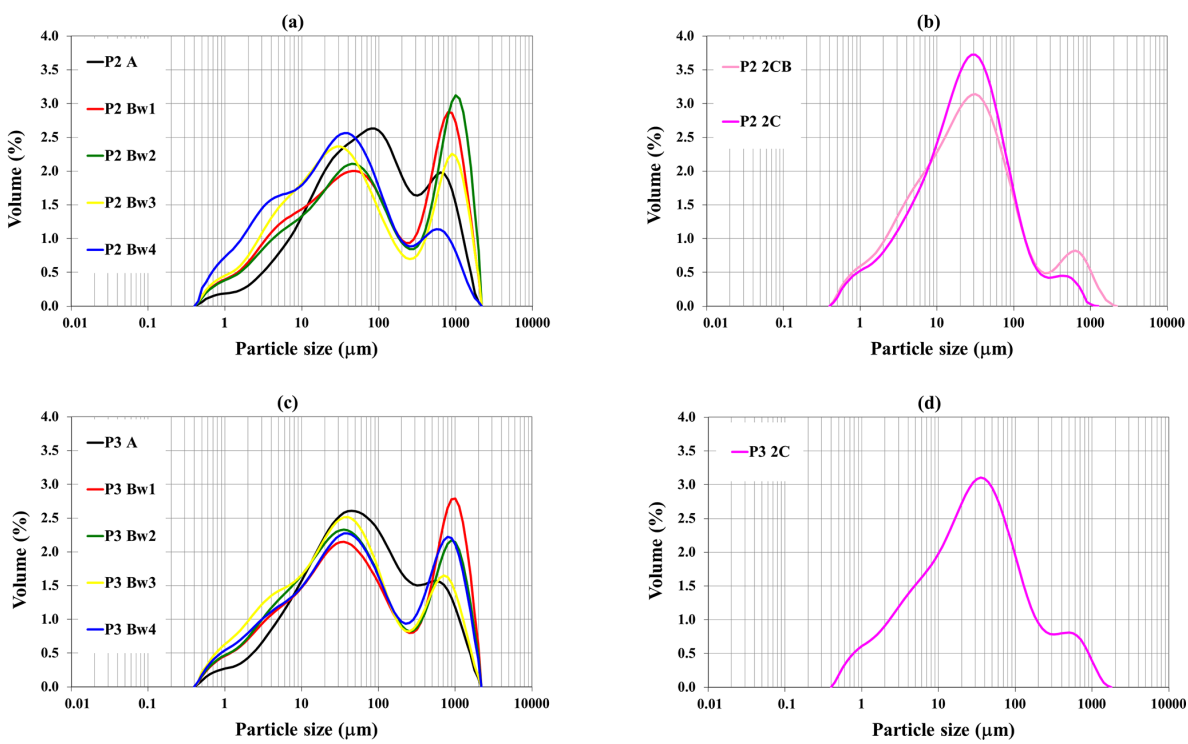

Figure 2. Particle size distribution (PSD) of (a) A and Bw horizons along soil profile $\mathrm{P} 2$ and (b) 2CB and 2C horizons along soil profile $\mathrm{P} 2$, (c) A and Bw horizons along soil profile $\mathrm{P} 3$, and (d) the $2 \mathrm{C}$ horizon along the soil profile $\mathrm{P} 3$.

\subsubsection{Hydraulic properties}

As a whole, the investigated horizons showed high water retention capacity. The saturated soil water content ranged from 0.56 to $0.64 \mathrm{~cm}^{3} \mathrm{~cm}^{-3}$, with a slight decrease from the surface to the bottom of the soil profile. The water retention curves and the equivalent pore size distributions of the selected horizons from P2 are shown in Fig. 3a and b, respectively. Due to the strong similarity between $\mathrm{P} 2$ and $\mathrm{P} 3$ hydrological data, the results of the $\mathrm{P} 3$ are not shown. The water re- 

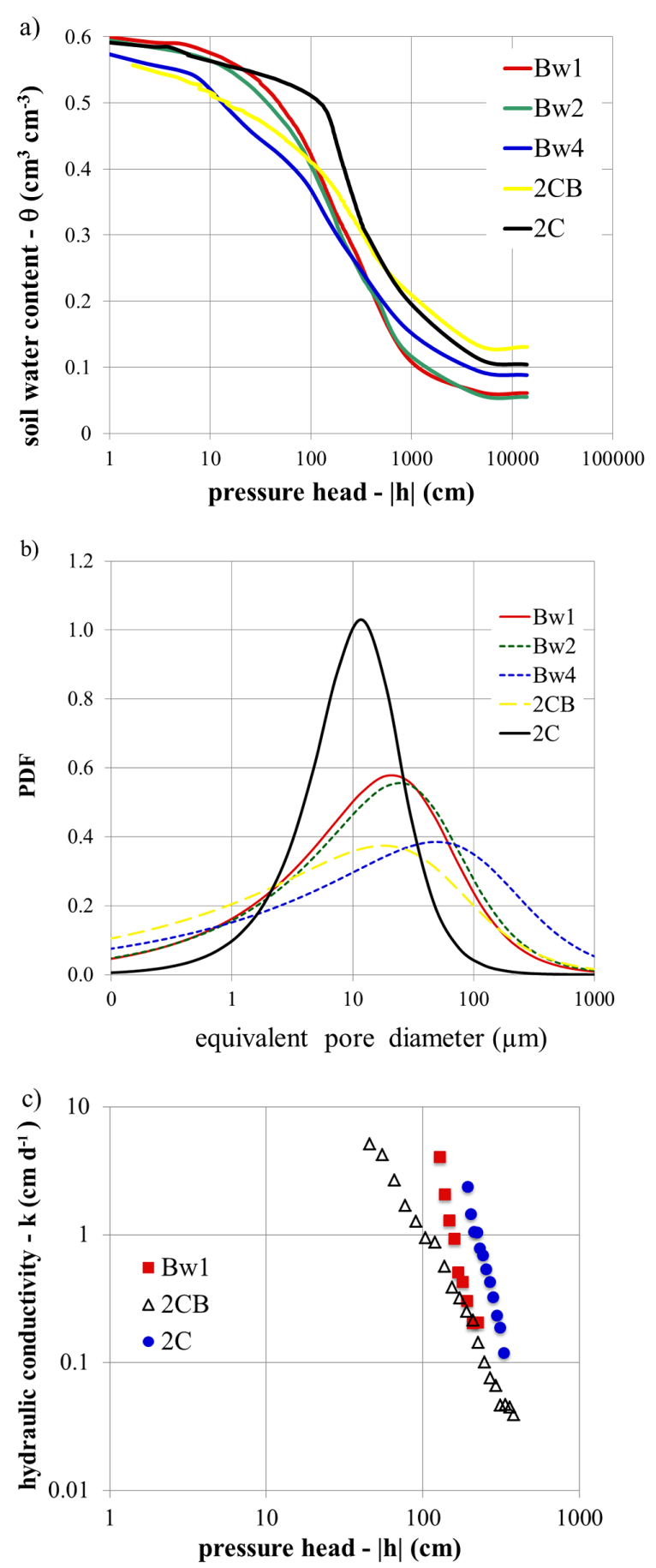

Figure 3. Hydraulic properties of selected horizons along soil profile P2: (a) water retention curves, (b) equivalent pore size distributions and (c) hydraulic conductivity curves.

tention curves of the Bw horizons showed a smoothed shape underlying a mesokurtic equivalent pore size distribution, indicating the presence of a wide range of pore diameters (Fig. 3b). Moreover, the Bw water retention curves exhibited a slight bimodality, with a secondary porous system having an equivalent pore dimension ranging between 1 and $10 \mathrm{~mm}$. This behaviour is common in many natural soils, where the presence of aggregates frequently results in pore size distributions with two or more peaks, which is reflected in water retention curves with at least two inflection points (Coppola et al., 2009). The shape of 2 C's retention curve was different, almost overlapping the others up to approximately $20 \mathrm{~cm}$, but decreasing sharply between 100 and $1000 \mathrm{~cm}$. This trend is related to a leptokurtic pore size distribution (Fig. 3b), with the prevailing class at $10 \mu \mathrm{m}$. An intermediate trend between the $\mathrm{Bw}$ and the $2 \mathrm{C}$ horizons was shown by the retention curve of $2 \mathrm{CB}$.

The unsaturated hydraulic conductivity curves of three $\left(\mathrm{Bw}_{1}, 2 \mathrm{CB}\right.$ and $\left.2 \mathrm{C}\right)$ selected horizons from $\mathrm{P} 2$ are shown in Fig. 3c. In the pressure head range where the measured curves overlap ( $h$ between -190 and $-330 \mathrm{~cm}$ ), the $2 \mathrm{C}$ horizon showed higher unsaturated hydraulic conductivity with respect to the upper horizons. This result is consistent with the steeper slope shown by $2 \mathrm{C}$ 's water retention curve in the same explored range. In fact, the relative hydraulic conductivity at a specific pressure head value is a function of the slope of the water retention curve at the same point, which is greater than its absolute value (Kutilek and Nielsen, 1994; Basile et al., 2006). Moreover, the saturated hydraulic conductivity values decreased with depth (Table 4). Indeed, the highest values were found along the upper $\mathrm{Bw}$ horizons $\left(k>100 \mathrm{~cm} \mathrm{~h}^{-1}\right)$, while they decreased by 1 order of magnitude for $\mathrm{Bw}_{4}$ and $2 \mathrm{CB}$ in $\mathrm{P} 2\left(k=80.7\right.$ and $\left.23.3 \mathrm{cmh}^{-1}\right)$, 2 orders of magnitude for $2 \mathrm{C}$ in $\mathrm{P} 2\left(k=5.5 \mathrm{~cm} \mathrm{~h}^{-1}\right)$, and 1 order of magnitude between $\mathrm{Bw}_{4}$ and $2 \mathrm{C}$ in $\mathrm{P} 3(k=200$ and $10.6 \mathrm{~cm} \mathrm{~h}^{-1}$ ). The different ranks along the depth of the saturated and unsaturated hydraulic conductivity are not surprising because these properties apply to different pore ranges.

\subsection{Optical microscopy}

Selected results from the micromorphological analyses of P2 are shown in Fig. 4. The surface of the A horizon showed a very fine granular structure, the presence of living roots, blackish granules and stains from decomposed plant residues (Fig. 4a). The following Bw horizon, which was characterised by a granular microstructure, exhibited very abundant (from 25 to $50 \%$ ) and generally unweathered pumice fragments enveloped by silty-fine sandy brown material (Fig. 4b). A clear microstructure change was observed in the deeper 2CB horizon, which was characterised by an incomplete sub-angular blocky microstructure that was less porous than that of the overlying layers. Angular to sub-angular peds (Fig. $4 \mathrm{c}_{1}$ and $\mathrm{c}_{2}$ ), which were made by pseudo-stratified materials, were found chaotically immersed in the soil matrix and interpreted as fragments of the underlying horizon (2C). The soil matrix and some aggregates from $2 \mathrm{CB}$ showed clay coatings in pores and likely neogenetic clays in pumice fragments (Fig. $4 \mathrm{~d}_{1}$ and $\mathrm{d}_{2}$ ), both indicating weathering processes. 
The following $2 \mathrm{C}$ horizon showed a thin stratification in the upper $6-7 \mathrm{~mm}$, which was commonly encrusted by $\mathrm{Fe}-\mathrm{Mn}$ segregations (Fig. 4e). Moreover, anisotropic clay coatings and frequent $\mathrm{Fe}-\mathrm{Mn}$ segregations (Fig. $4 \mathrm{f}_{1}$ and $\mathrm{f}_{2}$ ) coated the walls in a root pore located just above the described stratification and having the same direction. In the lower part, the $2 \mathrm{C}$ horizon became coarser, due to the occurrence of a layer with a single grain microstructure, with pores filled by clay materials (Fig. $4 \mathrm{~g}_{1}$ and $\mathrm{g}_{2}$ ).

\subsection{Microtomographic analyses}

Hydrological data provided an indirect evaluation of the pore arrangement through the equivalent pore size distribution; however, a direct evaluation of the real pore size distribution was achieved by image analysis (Fig. 5a). The interaggregate and intra-aggregate porosity were investigated using different image resolution limits (30 and $1.5 \mu \mathrm{m}$, respectively; pores smaller than pixel resolution cannot be detected). These values correspond roughly to -100 and $-2000 \mathrm{~cm}$ of pressure head, according to the capillary law. In Fig. $5 b_{1}$ the inter-aggregate PoSD $(>30 \mu \mathrm{m})$ of three representative $\mathrm{P} 2$ soil horizons $\left(\mathrm{Bw}_{4}, 2 \mathrm{CB}, 2 \mathrm{C}\right)$ is reported. The three curves exhibit very similar shapes, being unimodal and asymmetric to the right. $\mathrm{Bw}_{4}$ is characterised by the highest porosity (36.2\%), calculated by integrating the area under the curve, the highest modal value $(210 \mu \mathrm{m})$ of pore size and the widest pore size variability range, with the largest pores reaching a size of $2 \mathrm{~mm}$. By contrast, $2 \mathrm{C}$ has the lowest porosity (only $6.7 \%$ ), the lowest modal value of pore size $(150 \mu \mathrm{m})$ and a maximum pore size of $1 \mathrm{~mm}$, even though the most frequently found pore sizes were below $550 \mu \mathrm{m}$ (Fig. $5 b_{1}$ ). Measurements of the inter-aggregate connected porosity were reported in the three spatial directions by percolation curves (Fig. 5 $b_{2}$ ). These curves represent the percentage of the pore volume that connects opposite faces of the ROI, after the virtual occlusion of pores of increasing size. The curves of the three selected soil horizons exhibit different values of initial (no pore occlusion) connectivity and percolation thresholds (pt). The pt represents the maximum diameter that guarantees connectivity in a defined space direction. Therefore, the percolation curves can identify the critical sizes of pores that limit fluid and solute transport in any direction. All the samples showed an isotropic initial connectivity, with the highest and lowest values for $\mathrm{Bw}_{4}$ and $2 \mathrm{C}$, respectively. The results on the $z$ axis (Fig. 5 $\mathrm{b}_{2}$ ) showed a pt with higher $(510 \mu \mathrm{m})$ pore sizes for $\mathrm{Bw}_{4} \mathrm{com}$ pared to those of $2 \mathrm{C}(330 \mu \mathrm{m})$ and $2 \mathrm{CB}(270 \mu \mathrm{m})$. Because the $2 \mathrm{C}$ horizon's connected porosity was only $11 \%$ of the total porosity at $270 \mu \mathrm{m}$, the data for $2 \mathrm{C}$ and $2 \mathrm{CB}$ can be considered to be very similar. The pore connectivity along the other two $(x, y)$ directions (the horizontal plane) was not very different, with the $2 \mathrm{C}$ horizon showing the lowest pt at 210 and $150 \mu \mathrm{m}$ on the $x$ and $y$ axis, respectively. Therefore, in the range of the detected pore size $(>30 \mu \mathrm{m})$, the data seem
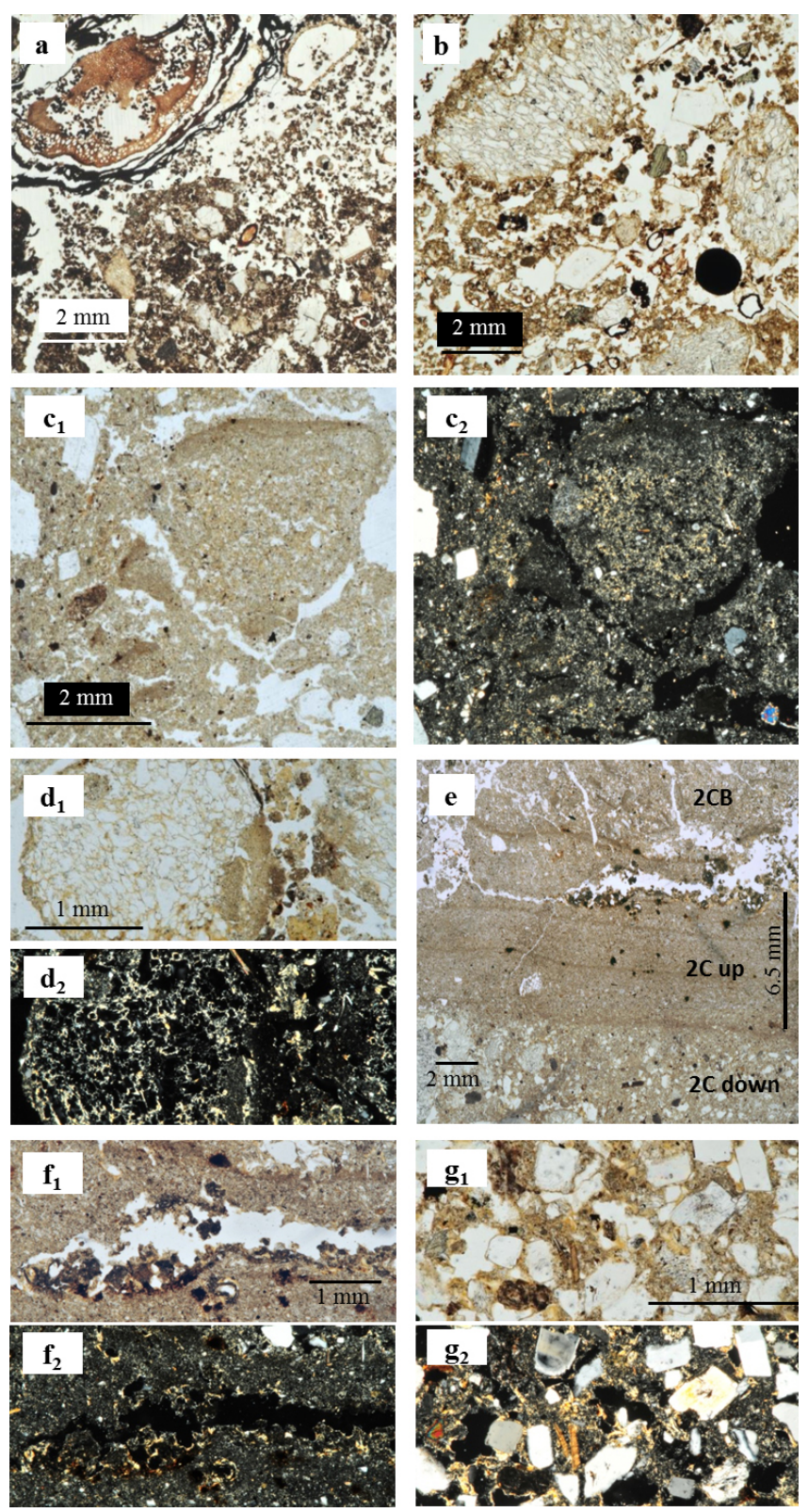

Figure 4. Optical microscopy: (a) very fine granular structure, presence of living roots and decomposed organic residues in the A horizon; (b) granular structure, showing very abundant (from 25 to $50 \%$ ) poorly weathered pumice fragments, enveloped by silty-fine sandy brown material, in the Bw horizon; (c) angular to sub-angular aggregates, pseudo-stratified by finer brownish and coarser materials and chaotically immersed in the soil matrix of the 2CB horizon ( $c_{1}$ and $c_{2}$ in PPL and XPL, respectively); (d) weathering and neogenetic clays in a pumice and clay coating fragments in a root pore $\left(\mathrm{d}_{1}\right.$ and $\mathrm{d}_{2}$ in PPL and XPL, respectively); (e) transition from $2 \mathrm{CB}$ towards the finely stratified upper part of $2 \mathrm{C}$; (f) root pore at the $2 \mathrm{CB}-2 \mathrm{C}$ boundary, in which anisotropic clay coatings and frequent $\mathrm{Fe}-\mathrm{Mn}$ segregations coat the walls ( $\mathrm{f}_{1}$ and $\mathrm{f}_{2}$ in PPL and XPL, respectively); (g) lower, coarser part of $2 \mathrm{C}$, which has a mineral granular structure with pores emptied by clay infillings ( $g_{1}$ and $g_{2}$ in PPL and XPL, respectively). 
(a)

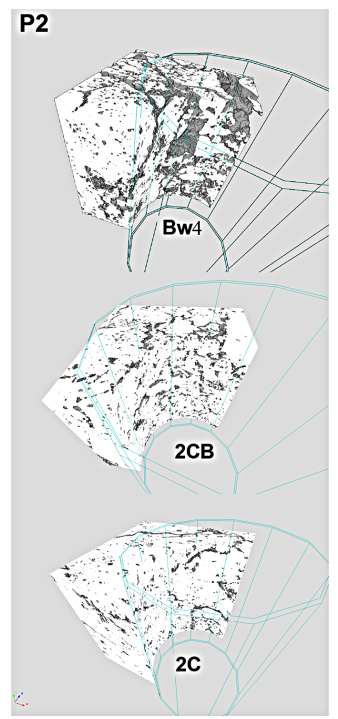

(c)

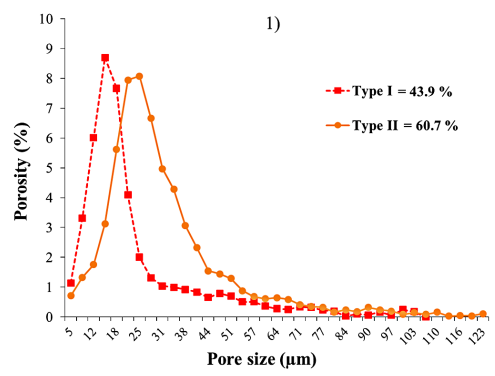

(b)

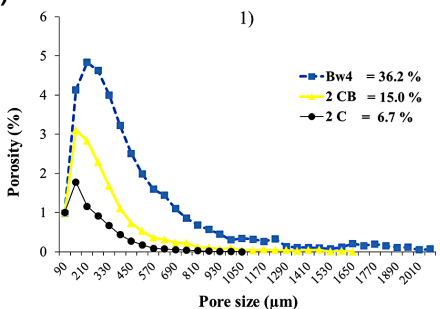

Pore size $(\mu \mathrm{m})$

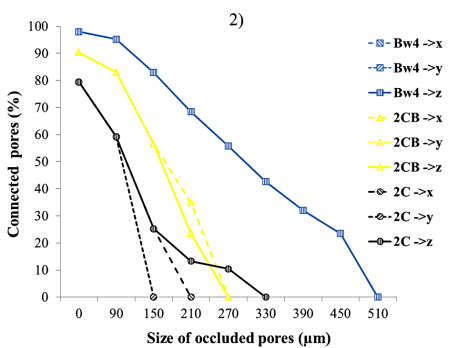

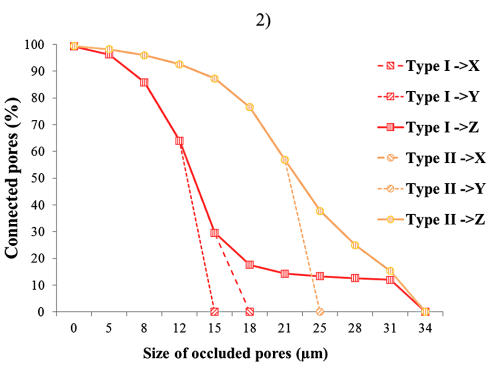

Figure 5. Microtomographic analysis: (a) $1.5 \mathrm{~cm}^{3} \times 1.5 \mathrm{~cm}^{3} \times 1.5 \mathrm{~cm}^{3}$ ROIs (regions of interests) of three soil horizons along soil profile P2 reconstructed by X-ray MicroCT (30 $\mathrm{m}$ image resolution) and (b) inter-aggregate (1) pore size distribution (PoSD) and (2) percolation curves (pore connectivity) from the 3-D image analysis of $\mathrm{Bw} 4,2 \mathrm{CB}$ and $2 \mathrm{C}$ along soil profile $\mathrm{P} 2$. The intersections between the percolation curves and abscissa represent the percolation threshold (pt) of the samples. Panel (c) shows intra-aggregate (1) PoSD and (2) pore connectivity from the 3-D image analysis of the two selected aggregates (types I and II) from 2C along soil profile P2.

to suggest the occurrence of an isotropic highly permeable horizon $(\mathrm{Bw})$ overlaying horizons with lower permeability (2CB and $2 \mathrm{C}$ ) in the soil profile. When we compared the porosity assessed by hydrological measurements with that obtained by the inter-aggregate microtomographic analyses (pores larger than $30 \mu \mathrm{m}$ ), the first values were, as expected, higher for all the analysed horizons, with the largest difference found for $2 \mathrm{C}$ (Table 5). The discrepancy in the data is mainly due to the applied resolution, and the largest difference was found for the $2 \mathrm{CB}$ and $2 \mathrm{C}$ horizons because they were mainly formed by pores smaller than $30 \mu \mathrm{m}$. Therefore, intra-aggregate porosity data were successively acquired on $2 \mathrm{C}$ using a resolution limit of $1.5 \mu \mathrm{m}$ (Fig. $5 \mathrm{c}_{1}$ ) to better investigate the porosity of the $2 \mathrm{C}$ horizon. The results showed two main types of aggregates that build this horizon: aggregate type I, which has internal massive microstructure, and aggregate type II, which has a micro fibric structure; both were characterised by high porosity ( 43.9 and $60.7 \%$, respectively) made by small pores ( 15 and $30 \mu \mathrm{m}$ modal class,
Table 5. Comparison between the porosity data obtained by hydrological and microtomographic measurements.

\begin{tabular}{llll}
\hline $\begin{array}{l}\text { Soil } \\
\text { horizons }\end{array}$ & \multicolumn{3}{c}{ Porosity $\%$} \\
\cline { 2 - 4 } & $\begin{array}{l}\text { Hydrological } \\
\text { data }\end{array}$ & $\begin{array}{l}\text { Inter-aggregate by } \\
\text { microtomography* }\end{array}$ & $\begin{array}{l}\text { Estimate } \\
\text { of pores } \\
\text { smaller } \\
\text { than } 30 \mu \mathrm{m}\end{array}$ \\
\hline Bw4 & 61 & 36 & 25 \\
$2 \mathrm{CB}$ & 57 & 15 & 42 \\
$2 \mathrm{C}$ & 61 & 7 & 54 \\
\hline
\end{tabular}

* more than $30 \mu \mathrm{m}$ resolution.

respectively) (Fig. 5c 1 ). Analysis of the pore connectivity (Fig. $5 c_{2}$ ) showed that $100 \%$ of the pores were interconnected in each direction but the percolation thresholds were very low (approximately $15-25 \mu \mathrm{m}$ ). 


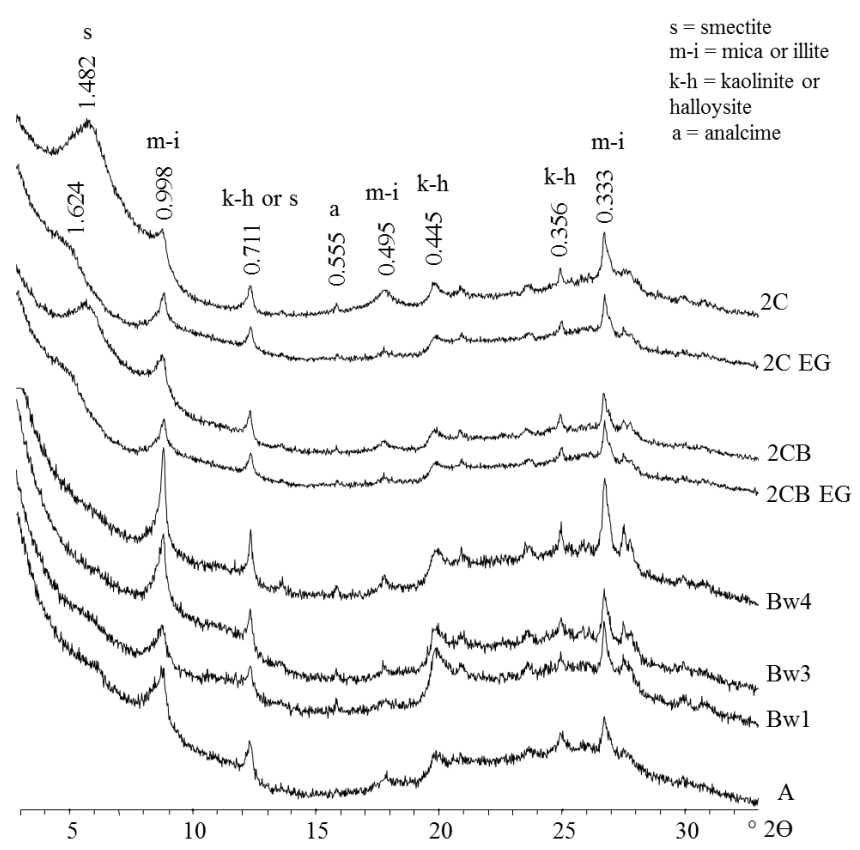

Figure 6. XRD patterns of untreated and treated (where EG is ethylene glycol solvated) clay samples separated from soil horizons along soil profile $\mathrm{P} 2$. Peak positions are in $\mathrm{nm}$.

\subsection{Clay mineralogy}

As a whole, K-feldspars (peaks at $0.647,0.334,0.324$ and $0.321 \mathrm{~nm})$ and mica $(0.994,0.500,0.448,0.332,0.257 \mathrm{~nm})$ were the minerals found in the sandy and silty fractions of both the soil horizons and ash deposits ( $2 \mathrm{C}$ horizons) (data not shown). By contrast, the XRD patterns of the clay fraction (Fig. 6) showed differences between the A-Bw horizons and 2CB-2C. Indeed, kaolinite and/or halloysite (0.711, $0.445,0.356 \mathrm{~nm})$, mica or illite $(0.998,0.495,0.333 \mathrm{~nm})$ and analcime $(0.555 \mathrm{~nm})$ peaks were found in all the horizons, whereas only $2 \mathrm{CB}$ and $2 \mathrm{C}$ showed $\sim 1.4 \mathrm{~nm}$ peaks $(1.48 \mathrm{~nm})$ in the Ca-saturated samples. After EG treatment, the $\sim 1.4 \mathrm{~nm}$ peaks shifted to $\sim 1.6 \mathrm{~nm}$ (Fig. 6 ), owing to the expandable nature of these clay minerals, which were then identified as smectites.

\section{Discussion}

\subsection{Ischia's soil properties}

As a whole, the results of the pedological study carried out on some head scarps of the Mt. Vezzi landslides show the occurrence of (i) topsoils with organic matter accumulation, very fine granular structure, a presence of living roots and blackish granules and stains from decomposed plant residues, which are frequent features of forestry soils (Bullock et al., 1985; Stoops, 2003; Blazejewski et al., 2005; Stolt and Lindbo, 2010). Results also show occurrence of (ii) subsoils with weakly- to moderately-developed soil structure of yellowish and greyish colours; this suggests a generally low degree of weathering, as a consequence of scarce iron oxide formation. The higher $\mathrm{Fe}_{\mathrm{o}} / \mathrm{Fe}_{\mathrm{d}}$ ratios decreasing with depth $(0.7-0.1)$ lead us to conclude that the deeper horizons had undergone a higher degree of weathering than the upper horizons. Although these soils originated from volcanic parent material, they do not exhibit andic properties (as defined by IUSS Working Group WRB, 2014), instead displaying vitric properties in a few horizons in P1. Similar to other volcanic soils of the Campania region (di Gennaro and Terribile, 1999; di Gennaro et al., 2002), the chemical and physical properties of Ischia's soils exhibit large spatial variability in both the horizontal and vertical directions among pedons. The main abrupt variation in the soil's properties is identified at variable depths between $70 / 90$ and $205 \mathrm{~cm}$, where pumice-bearing soil horizons ( $\mathrm{A}$ and $\mathrm{Bw}$ ) overlie fine ashes (2CB and/or $2 \mathrm{C})$, with the silt content increasing by $20 \%$. These fine ashes were found in all the studied soil profiles and were only marginally involved with the sliding surface of the recorded landslides (De Vita et al., 2007). According to the abrupt discontinuity, a relevant change of the physical, micromorphological and mineralogical properties was found. Indeed, the inter-aggregate porosity, which was investigated by means of microtomographic analyses, shows remarkable differences between the $\mathrm{Bw}$ and $2 \mathrm{C}$ horizons in terms of the following: (i) total porosity larger than $30 \mu \mathrm{m}$ (36.2 and $6.7 \%$, respectively); (ii) mode of the pore size distribution (210 and $150 \mu \mathrm{m}$, respectively); (iii) maximum pore size, which is larger in $\mathrm{Bw}(\leq 2 \mathrm{~mm})$ than in $2 \mathrm{C}$ $(\leq 1 \mathrm{~mm}$ ); and (iv) connected porosity (percolation thresholds at approximately $500 \mu \mathrm{m}$ and $150-225 \mu \mathrm{m}$ pore size, respectively). Moreover, the intra-aggregate (in the range of $30-1.5 \mu \mathrm{m}$ ) connected porosity, which was measured only in $2 \mathrm{C}$, shows the occurrence of aggregates characterised by high total porosity $(60.7-43.9 \%)$ made by small pores (15$30 \mu \mathrm{m}$ modal class) and a very low percolation threshold (approximately $15-25 \mu \mathrm{m}$ ) which lower the permeability of the pore network. The pore connectivity, combined with the very high porosity values, fully agrees with the high water retention found by the hydrological analyses in this horizon. In fact, the full connectivity of the intra-aggregate pore network allows complete water saturation of the $2 \mathrm{C}$ horizon, whereas small pores with low percolation thresholds require high energy to remove water from such a system. Data of intra-aggregate connected porosity are also consistent with the general decrease in saturated hydraulic conductivity $\left(k_{\mathrm{s}}\right)$ that is also observed with depth, with the lowest values found in $2 \mathrm{C}$. Nevertheless, the $k_{\mathrm{s}}$ value of $2 \mathrm{C}$ is still high, and the authors believe that this horizon cannot be considered an impeding layer (i.e. a horizon with a low $k_{\mathrm{S}}$ value), which can determine waterlogging conditions. By comparing the $k_{\mathrm{s}}$ values obtained in the laboratory (this study) and those measured in the field (De Vita et al., 2007) on the same soil horizons (horizons Bw, 2CB 
and $2 \mathrm{C}$ correspond to $\mathrm{B}, \mathrm{C}_{1}$ and $\mathrm{C}_{2}$ in De Vita et al., 2007), the following were observed: (i) generally lower values of $k_{\mathrm{S}}$ measured in the field $\left(1 \times 10^{-2} \mathrm{~cm} \mathrm{~s}^{-1}\right.$ measured for $\mathrm{B}$ and $1 \times 10^{-5} \mathrm{~cm} \mathrm{~s}^{-1}$ for $2 \mathrm{C}$ ) than those measured in the laboratory (see Table 4), but (ii) consistent trends between the laboratory and field data, both characterised by decreasing values with depth. It has been shown (Eching et al., 1994; Rockhold et al., 1996; Basile, 2004, unpublished data, among others) that laboratory-determined $k_{\mathrm{S}}$ values can be 1 or more orders of magnitude greater than those measured in the field. Therefore, if we look only at the field data, the very low $k_{\mathrm{s}}$ values really indicate $2 \mathrm{C}$ as an impeding layer, but this contrasts with what was reported above from the evaluation of the laboratory $k_{\mathrm{s}}$ measurements. The results of the micromorphological analyses enable us to clarify this apparent inconsistency. Indeed, the occurrence of a thin $(6.5 \mathrm{~mm})$ slightly porous layer, which consists of finely stratified ashes, at the $2 \mathrm{CB} / 2 \mathrm{C}$ interface in $\mathrm{P} 2$ very likely represents an obstacle to vertical and horizontal water fluxes, favouring (possibly temporary) waterlogging and hydromorphic conditions, as shown by the hydromorphic features (e.g. Fe / Mn concretions) found on top of and within the layer. The $2 \mathrm{CB}$ horizon is interpreted as the upper part of $2 \mathrm{C}$ reworked by pedofauna activity. Due to the very low thickness, the authors suppose that the stratified layer was not sampled for the hydrological laboratory measurements and therefore did not affect the results.

The presence of clay coatings in the pore spaces of $2 \mathrm{CB}$ and $2 \mathrm{C}$ probably increased the waterlogging conditions created by the thin ash layer above $2 \mathrm{C}$ because the swelling clay particles, which expand during hydration, could also reduce the pore space for water fluxes. This process is certainly aided by the occurrence of $\mathrm{Na}$, which has been found in the whole profile but increases with depth, because this cation causes clay hydration and deflocculation, which worsen the soil's physical properties (Basile et al., 2012). However, despite the fact that $\mathrm{Na}$ content is higher than $15 \%$ in the deepest horizons of the three profiles, these horizons lack the requirements of salic or natric horizons (IUSS Working Group WRB, 2014) in terms of electrical conductivity $\left(\mathrm{EC}<15 \mathrm{dS} \mathrm{m}^{-1}\right)$, soil structure and texture. The origin of the $\mathrm{Na}$ in these soils is probably related to the alkaline trachytic composition of the volcanic ash (Vezzoli, 1988).

\subsection{Comparison between soils from Ischia and elsewhere in Campania that were affected by debris-mudflows}

Despite the common landforms (high gradient north-facing slope), similar forestry (mixed chestnut woodland: coppice), volcanic origin of the parent material, and the same movement types of the triggered landslides, the results of this study indicate significant differences in terms of particular properties between the soils from Mt. Vezzi (MV) and elsewhere in Campania (CA) that were commonly involved in debris-mudflows (Terribile et al., 2000, 2007; Basile et al., 2003). Indeed, as a whole, both MV and CA are characterised by shallow surface horizons, which store the most OC content of these soils (49-71 and $28-98 \mathrm{~g} \mathrm{~kg}^{-1}$, respectively), and thick deep horizons, which generally show lower OC content in MV than in CA (2.3-12.3 and 2.2-32.7 $\mathrm{g} \mathrm{kg}^{-1}$, respectively). Similar soil reactions ( $\mathrm{pH}$ ranging between 6.0 and 7.6 in MV and between 6.5 and 8.3 in CA) and comparable saturated water content $(0.56-0.64$ and $0.50-$ $0.75 \mathrm{~cm}^{3} \mathrm{~cm}^{-3}$ in $\mathrm{MV}$ and CA, respectively) are found in both soil groups, along with saturated hydraulic conductivity, which is generally high and decreases with depth. The saturated water content of both MV and CA is indicative of a complex porous system, similar to that shown by the Andosols, which are well known for their high water retention capacity (Basile et al., 2007). In spite of that, a remarkable difference between MV and CA occurs in terms of andic properties: the former soils do not exhibit andic properties, whereas the latter are well developed Andosols. As a consequence, thixotropy is absent from MV but well developed in $\mathrm{CA}$, which is consistent with the development of andic properties.

As stated above, both MV and CA developed in very similar environments, in terms of geomorphological factors, land use and parent material.

Regarding the time of pedogenesis, two main causes increase the difficulty of dating the soil: (i) certain chronological references (e.g. identified volcanological markers) are not available for all the studied Campania soils (Terribile et al., 2007) and (ii) erosion/deposition processes frequently occur on these high gradient slopes. Moreover, soil rejuvenation problems could also be verified for sites where volcanological markers are recognised along the soil profiles. Indeed, in the case of MV, where the Piano Liguori formation (5.3-5.8 kyrs BP) was identified at the bottom of the soil, the more recent Cretaio Tephra (first-second century AD) might have arrived in the area (De Vita et al., 2010), rejuvenating the soils. In the case of Sarno and Quindici, the markers of the Vesuvius Pomici di Avellino eruption (dated 3.9 kyrs by Mastrolorenzo et al., 2006), found on the slopes (Di Vito et al., 2008) and along the soil profile (Terribile et al., 2000), could represent a chronological constraint for dating these soils. Nevertheless, as reported by Zanchetta et al. (2004), the markers of more recent Vesuvius eruptions (such as Pollena $\mathrm{AD}$ 472) have reached many slopes along Campania's reliefs and could have affected the pedogenesis.

Concerning the climate, the average yearly rainfall between 1960 and 1990 (data from ISPRA SINTAI, 2005) shows that Ischia (Ischia Ponte Pilastri station registered an average annual rainfall of $850 \mathrm{~mm}$ ) is drier compared to the inland areas of the Campania region (Montevergine station registered an average annual rainfall of $1857 \mathrm{~mm}$ ). Therefore, the difference in the andic properties within these soils is predominantly due to the climatic conditions of the pedogenetic 
environments, which are known to strongly affect andosolisation processes (Shoji et al., 1993).

Therefore, the occurrence of debris and mudflows in "nonandic" soils, such as those of MV, enables us to give additional and stronger relevance, in terms of the predisposing factor to the occurrence of landslides, to abrupt spatial variability in the soil's (physical) properties, even at a microscopic level.

\section{Conclusions}

The soil study carried out at Mt. Vezzi enabled us to identify generally young and deep volcanic soils that show vitric properties but not andic properties. The latter were widely found in soils involved in other debris-mudflows in Campania (Terribile et al., 2007).

Therefore, the results suggest a more complex relationship between soil properties and debris-mudflows in the region and underline the role played by the vertical variability of the soil properties as an environmental predisposing factor to landslide phenomena. Specifically, a significant discontinuity was identified at Mt. Vezzi over various depths (70/90$190 \mathrm{~cm}$ ) at the interface of the B and 2C horizons, in terms of the physical (i.e. different particle size distribution, pore size and connected porosity, anisotropy of hydraulic conductivity), chemical (i.e. Na enriched deep horizon) and mineralogical (i.e. swelling clays only in the deep horizons) properties. Moreover, the identification of a thin, finely stratified ashy layer above $2 \mathrm{C}$ by means of optical microscopy emphasised the role of $2 \mathrm{C}$ as an impeding layer and predisposing factor to landslides. Indeed, under heavy rainfall or prolonged phases of light rainfall, this layer further reduces vertical water fluxes and leads to an increase in soil water storage in the overlying soil horizons, increasing the instability along the slope because of the higher soil weight.

According to the observations on the Mt. Vezzi landscape and other debris-mudflows in Campania, these are very fragile ecosystems due to frequent human disturbances, including soil mantle cutting for trackways and the unplanned cutting of woodlands, which could increase the water stored in the profile from approximately 30-45\% (Basile et al., 2003). Therefore, further investigations on the spatial distribution of both (i) the high soil thickness above the "impeding layers" and (ii) road cut/naturally steep walls are needed to identify the "highest risk areas" for landslides and to safeguard these precious (e.g. in terms of biomass production) and highly vulnerable forest ecosystems.

Author contributions. S. Vingiani, R. De Mascellis and F. Terribile sampled the soils in the landslide detachment crowns. S. Vingiani designed the experiments and carried out the chemical and the mineralogical analyses. S. Vingiani and F. Terribile analysed thin soil sections by means of the micromorphological methodologies. A. Basile and R. De Mascellis designed and performed particle size distribution and hydrological measurements. G. Mele planned and carried out the microtomographic analyses. S. Vingiani and A. Basile prepared the manuscript with contributions from all the co-authors.

Acknowledgements. The authors thank Luciana Minieri (Department of Agriculture, University of Naples Federico II) and Nadia Orefice (CNR ISAFOM, Ercolano NA) for the measurement of some chemical and physical soil properties.

Edited by: P. Pereira

\section{References}

Arya, L. M.: Wind and hot-air methods, in: Methods of Soil Analysis. Part 4. Physical Methods, SSSA Book Series 5, SSSA, Madison, 916-926, 2002.

Ascione, A., Cinque, A., Franza, A., and Romano, P.: The geomorphic control on the initiation and propagation of the Mt. Vezzi landslides (Ischia island, Italy) occurred on 30th April 2006, Italian Journal of Engineering Geology and Environment, 2, 93-118, 2007.

Bascomb, C. L.: Distribution of pyrophosphate extractable iron and organic carbons in soils of various groups, J. Soil Sci., 19, 251268, 1968.

Basile, A., Mele, G., and Terribile, F.: Soil hydraulic behaviour of a selected benchmark soil involved in the landslide of Sarno 1998, Geoderma, 117, 331-346, 2003.

Basile, A., Coppola, A., De Mascellis, R., and Randazzo, L.: Scaling approach to deduce field unsaturated hydraulic properties and behavior from laboratory measurements on small cores, Vadose Zone J., 5, 1005-1016, 2006.

Basile, A., Coppola, A., De Mascellis, R., Mele, G., and Terribile, F.: A comparative analysis of the pore system in volcanic soils by means of water-retention measurements and image analysis, in: Soils of Volcanic Regions in Europe, Springer, Berlin, 493-513, 2007

Basile, A., Buttafuoco, G., Mele, G., and Tedeschi, A.: Complementary techniques to assess physical properties of a fine soil irrigated with saline water, Environmental Earth Sciences, 66, 1797-1807, 2012.

Blakemore, L. C., Searle, P. L., and Daly, B. K.: Methods for Chemical Analysis of Soils, New Zealand Soil Bureau scientific report 80, NZ Soil Bureau, Department of Scientific and Industrial Research, Lower Hutt, 1987.

Blazejewski, G. A., Stolt, M. H., Gold, A. J., and Groffman, P. M.: Macro- and micromorphology of subsurface carbon in riparian zone soils, Soil Sci. Soc. Am. J., 69, 1320-1329, 2005.

Bonfante, A., Basile, A., Acutis, M., Perego, A., and Terribile, F.: SWAP, CropSyst and MACRO comparison in two contrasting soils cropped with maize in Northern Italy, Agr. Water Manage., 97, 1051-1062, 2010.

Bullock, P., Fedoroff, N., Jongerius A., Stoops, G., Tursina, T., and Babel, U.: Handbook for Soil Thin Section Description. Waine Research Publications, Wolverhampton, UK, 152 pp., 1985. 
Childs, C. W.: Towards understanding soil mineralogy. II: Notes on ferrihydrite, NZ Soil Bureau Laboratory Report CM7, NZ Soil Bureau, Lower Hutt, New Zealand, 16 pp., 1985.

Civetta, L., Gallo, G., and Orsi, G.: Sr- and Nd-isotope and traceelement constraints on the chemical evolution of the magmatic system of Ischia (Italy) in the last $55 \mathrm{Ka}$, J. Volcanol. Geoth. Res., 46, 213-244, 1991.

Coppola, A., Basile, A., Comegna, A., and Lamaddalena, N.: Monte Carlo analysis of field water flow comparing uni-and bimodal effective hydraulic parameters for structured soil, J. Contam. Hydrol., 104, 153-165, 2009.

Cruden, D. M. and Varnes, D. J.: Landslides types and processes, in: Landslides: Investigation and Mitigation, Special Report 247, Transportation Research Board, National Research Council, edited by: Turner, A. K. and Schuster, R. J., National Academy Press, Washington, DC, 36-75, 1996.

De Vita, P., Di Clemente, E., Rolandi, M., and Celico, P.: Engineering geological models of the initial landslides occurred on April 30th 2006, at the Mount di Vezzi (Ischia island, Italy), Italian Journal of Engineering Geology and Environment, 2, 119-141, 2007.

De Vita, S., Sansivero, F., Orsi, G., Marotta, E., and Piochi, M.: Volcanological and structural evolution of the Ischia resurgent caldera (Italy) over the past $10 \mathrm{ka}$, in: Stratigraphy and Geology in Volcanic Areas, edited by: Groppelli, G. and Viereck, L., Geological Society of America Book Series, Special Paper 464, 193 239, 2010.

di Gennaro, A. and Terribile, F.: I suoli della provincia di Napoli, Carta 1 : 75.000 e Legenda, Ge.PRO.TER., SELCA, Firenze, 163, 1999.

di Gennaro, A., Aronne, G., De Mascellis, R., Vingiani, S., Sarnataro, M., and Cona, F.: I sistemi di Terre della Campania, Risorsa s.r.1., SELCA, Firenze, 1-63, 2002.

Di Nocera, S., Matano, F., Rolandi, G., and Rolandi, R.: Contributo sugli aspetti geologici e vulcanologici di Monte di Vezzi (Isola d'Ischia) per lo studio degli eventi franosi dell'aprile 2006, Italian Journal of Engineerig Geology and Environment, 2, 27-50, 2007.

Di Vito, M. A., Sulpizio, R., Zanchetta, G., and D'Orazio, M.: The late Pleistocene pyroclastic deposits of the Campanian Plain: new insights into the explosive activity of Neapolitan Volcanoes, J. Volcanol. Geoth. Res., 177, 19-48, 2008.

Eching, S. O., Hopmans, J. W., and Wallender, W. W: Estimation of in situ unsaturated soil hydraulic functions from scaled cumulative drainage data, Water Resour. Res., 30, 2387-2394, 1994.

FAO: Guidelines for Soil Profile Description, 3rd Edn., Soil Resources Management and Conservation Service, Land and Water Development Division, FAO, Rome, revised, 1990.

Fields, M. and Parrott., K. W.: The nature of allophane in soils. III. Rapid field and laboratory test for allophane, New Zeal. J. Sci., 9, 623-629, 1966.

FitzPatrick, E. A.: Micromorphology of Soils, Chapman and Hall, London, 433 pp., 1984.

FitzPatrick, E. A.: Soil Microscopy and Micromorphology, Wiley, West Sussex, England, 304 pp., 1993.

Glendon, G. W. and Dani, O.: 2.4 Particle-size analysis, in: Methods of soil analysis, edited by: Dane, J. H. and Topp, G. C., Part 4, Physical Methods, 255-293, Madison, Wisconsin, USA, Soil Science Society of America, Inc., 2002.
Guzzetti, F. and Tonelli, G.: Information system on hydrological and geomorphological catastrophes in Italy (SICI): a tool for managing landslide and flood hazards, Nat. Hazards Earth Syst. Sci., 4, 213-232, doi:10.5194/nhess-4-213-2004, 2004.

Guzzetti, F., Cardinali, M., and Reichenbach, P.: The AVI Project: a bibliographical and archive inventory of landslides and floods in Italy, Environ. Manage., 18, 623-633, 1994.

Horgan, G. W.: Mathematical morphology for analysing soil structure from images, Eur. J. Soil Sci., 49, 161-173, 1998.

Hungr, O., Evans, S. G., Bovis, M. J., and Hutchinson, J. N.: A review of the classification of landslides of the flow type, Environ. Eng. Geosci., 7, 221-238, 2001.

ISPRA - SINTAI: Progetto Annali, Banca dati, available at: http: //www.acq.isprambiente.it/annalipdf/, last access: 19 December 2014, 2005.

IUSS Working Group WRB: World Reference Base for Soil Resources 2014, International soil classification system for naming soils andcreating legends for soil map, World Soil Resources Reports No. 106., FAO, Rome, 2014

Jurin, J.: An account of some experiments shown before the Royal Society; with an enquiry into the cause of the ascent and suspension of water in capillary tubes, Philos. T. R. Soc. Lond., 30, 739-747, 1718.

Kak, A. C. and Slaney, M.: Principles of Computerized Tomographic Imaging, IEEE Press, Piscataway, NJ, 1988.

Kutilek, M. and Nielsen, D. R.: Soil Hydrology, Catena Verlag, Geoscience Publication, Cremlingen Destedt, Germany, 370 pp., 1994.

Lantuejoul, C. and Maisonneuve, F.: Geodesic methods in quantitative image analysis, Pattern Recogn., 17, 177-187, 1984.

La Stampa: Il Paese con più catastrofi in Europa, Oltre 2 mila morti negli ultimi 50 anni, available at: http://geomorphology.irpi.cnr.it/media/2014/ (last access: 19 December 2014), 2014.

Lesch, S. M. and Suarez, D. L.: A short note on calculating the adjusted SAR index, T. ASABE, 52, 493-496, 2009.

Mastrolorenzo, G., Petrone, P., Pappalardo, L., and Sheridan, M.: The Avellino 3780-yr-B.P. catastrophe as a worst-case scenario for a future eruption at Vesuvius, P. Natl, Acad. Sci. USA, 103, 4366-4370, 2006.

Mazzarella, A. and De Luise, E.: The meteoric event of 30th April 2006 at Ischia island, Italy, Italian Journal of Engineering Geology and Environment, 2, 7-14, 2007.

Mehlich, A.: Use of triethanolamine acetate-barium hydroxide buffer for the determination of some base exchange properties and lime requirement of soil, Soil Sci. Soc. Am. Pro., 29, 374378, 1938.

Mehra, O. P. and Jackson, M. L.: Iron oxide removal from soils and clays by a dithionite-citrate system buffered with sodium bicarbonate, Clay. Clay Miner., 7, 317-327, 1960.

Orsi, G., de Vita, S., and Di Vito, M.: The restless, resurgent Campi Flegrei nested caldera (Italy): constraints on its evolution and configuration, J. Volcanol. Geoth. Res., 74, 179-214, 1996.

Parfitt, R. L.: Allophane in New Zealand - a review, Aust. J. Soil Res., 28, 343-360, 1990.

Parfitt, R. L. and Wilson, A. D.: Estimation of allophane and halloysite in three sequences of volcanic soils, New Zealand, in: Volcanic Soils: Weathering and Landscape Relationships of Soils 
on Tephra and Basalt, Catena Suppl. 7, Catena Verlag, Cremlingen, Germany, 1-8, 1985 .

Reynolds, W. D. and Elrick, D. E.: The soil solution phase. Falling head soil core (tank) method, in: Methods of Soil Analysis, edited by: Dane, J. H. and Topp, G. C., SSSA Book Ser., vol. 5., 809-812, SSSA, Madison, WI, USA, 2003.

Rittmann, A. and Gottini, V.: L'Isola d'Ischia - geologia, Boll. Serv. Geol. Ital., 101, 131-274, 1980.

Schwertmann, U.: Differenzierung der Eisenoxide des Bodens durch photochemische Extraktion mit saurer Ammoniumoxalatlosung, Lösung, Z. Pflanzenernähr. Düng. Bodenkde., 105, 194202, 1964.

Serra, J.: Image Analysis and Mathematical Morphology, Academic Press, London, 1982.

Shoji, S., Dahlgren, R., and Nanzyo, M.: Genesis of volcanic ash soils, in: Volcanic Ash Soils. Genesis, Properties and Utilization. Developments in Soil Science, 21, 37-71, Elsevier, Amsterdam, London, New York, Tokyo, 1993.

SSS (Soil Survey Staff): Kellogg Soil Survey Laboratory Methods Manual, Soil Survey Investigations Report No. 42, Version 5.0, edited by: Burt, R. and Soil Survey Staff, U.S. Department of Agriculture, Natural Resources Conservation Service, Lincoln, Nebraska, 2014.

Stolt, M. H. and Lindbo, D. L.: Soil organic matter, in: Interpretation of Micromorphological Features of Soils and Regoliths, edited by: Stoops, G., Marcelino, V., and Mees, F., Elsevier, Amsterdam, 369-396, 2010.

Stoops, G.: Guidelines for Analysis and Description of Soil and Regolith Thin Sections, Soil Science Society of America, Madison, Wisconsin, 184 pp., 2003.
Terribile, F., Basile, A., De Mascellis, R., Di Gennaro, A., Mele, G., and Vingiani, S.: I suoli delle aree di crisi di Quindici e Sarno: proprietà e comportamenti in relazione ai fenomeni franosi, Quaderni di Geologia Applicata, 7, 59-79, 2000.

Terribile, F., Basile, A., De Mascellis, R., Iamarino, M., Magliulo, P., Pepe, S., and Vingiani, S.: Landslide processes and andosols: the case study of the Campania region, Italy, in: Soils of Volcanic Regions in Europe: Volcanic Soils and Land Use, edited by: Arnalds, Ó., Bartoli, F., Buurman, P., Óskarsson, H., Stoops, G., García-Rodeja, E., Springer, Berlin, Heidelberg, New York, 545-563, 2007.

Vezzoli, L.: Island of Ischia, in: Quaderni de la "Ricerca Scientifica”, Consiglio Nazionale delle Ricerche (CNR), Roma 1988, P.F.G., 114, 51-72, 1988.

Vingiani, S. and Terribile, F.: Soils of the detachment crowns of Ischia landslides, Italian Journal of Engineering Geology and Environment, 2, 51-63, 2007.

Walkley, A. and Black, I. A.: An examination of the Degtjareff method for determining organic carbon in soils: effect of variations in digestion conditions and of inorganic soil constituents, Soil Sci., 63, 251-263, 1934.

Watson, K. K.: An instantaneous profile method for determining the hydraulic conductivity of unsaturated porous materials, Water Resour. Res., 2, 709-715, 1966.

Wells, N. and Furkert, R. J.: Bonding of water to allophane, Soil Sci., 113, 110-115, 1972.

Zanchetta, G., Sulpizio, R., and Di Vito, M. A.: The role of volcanic activity and climate in alluvial fan growth at volcanic areas: an example from southern Campania (Italy), Sediment. Geol., 168, 249-280, 2004. 